OPEN ACCESS

Edited by:

Junsheng Nie,

Lanzhou University, China

Reviewed by:

David Anastasio

Lehigh University, United States

Liang Yi,

Tongji University, China

${ }^{*}$ Correspondence:

Hamdi Omar

hamdi.omar@enis.tn

Specialty section:

This article was submitted to Geomagnetism and Paleomagnetism, a section of the journal

Frontiers in Earth Science

Received: 06 December 2020

Accepted: 26 February 2021

Published: 26 March 2021

Citation:

Omar H, Da Silva A-C and Yaich C

(2021) Linking the Variation of Sediment Accumulation Rate to Short

Term Sea-Level Change Using Cyclostratigraphy: Case Study of the

Lower Berriasian Hemipelagic Sediments in Central Tunisia (Southern Tethys). Front. Earth Sci. 9:638441

doi: 10.3389/feart.2021.638441

\section{Linking the Variation of Sediment Accumulation Rate to Short Term Sea-Level Change Using Cyclostratigraphy: Case Study of the Lower Berriasian Hemipelagic Sediments in Central Tunisia (Southern Tethys)}

\author{
Hamdi Omar ${ }^{1,2 *}$, Anne-Christine Da Silva ${ }^{3}$ and Chokri Yaich ${ }^{1,2}$
}

\begin{abstract}
${ }^{1}$ Department of Geological Engineering, National Engineering School of Sfax, Sfax University, Sfax, Tunisia, ${ }^{2}$ Laboratory of Georessources, Materials Environment and Global Change, Faculty of Sciences of Sfax, University of Sfax, Sfax, Tunisia,

${ }^{3}$ Sedimentary Petrology Laboratory, Liège University, Liège, Belgium
\end{abstract}

High-resolution magnetic susceptibility and $\% \mathrm{CaCO}_{3}$ records (5 to $10 \mathrm{~cm}$ sampling interval) are used to track astronomical cycles from a Lower Berriasian record from central Tunisia. Six hundred and twenty two samples were measured for magnetic susceptibility and carbonate content as paleoclimate proxies for the detection of potential Milankovitch cycles. Elemental data using X-Ray fluorescence analyses was acquired from 19 samples to prove the reliability of the MS signal on recording the past paleoclimatic changes. We performed multiple spectral analyses and statistical techniques on the magnetic susceptibility signal, such as Multi-taper Method, Evolutive Harmonic Analysis, Correlation Coefficient, Time-optimization, and Average Spectral Misfit to obtain an optimal astronomical model. The application of these spectral analysis techniques revealed a pervasive dominance of $E_{405}-k y r$ and $e_{100}-k y r$ cycles showing that the climate turnover across the early Berriasian-middle Berriasian seems to had been governed by the long and short orbital eccentricity cycles. The identification of Milankovitch cycles in the record also allowed to propose a floating astronomical timescale of the studied section, with $\sim 4$ long eccentricity cycles $\left(E_{405}\right)$ extracted, which points to a duration estimate of $\sim 1.6 \mathrm{Myr}$ with an average sediment accumulation rate (SAR, after compaction) of $2.77 \mathrm{~cm} / \mathrm{kyr}$. The inferred floating ATS was tuned to the La2004 astronomical solution. In addition, we applied the DYNOT and $\rho 1$ methods for seal-level change modeling to reconstruct a local eustatic profile which matches the previously published local and global eustatic charts.

Keywords: Berriasian, cyclostratigraphy, Sidi Khalif formation, orbital tuning, sediment accumulation rate 


\section{INTRODUCTION}

The Cretaceous is the only system/period of the Phanerozoic that has not yet been defined by a basal GSSP. The Berriasian base $[145.7 \pm 0.8$ (GTS 2016) vs. $145.0 \pm 0.8$ (GTS2012)] is defined as follow: In GTS2012, a working definition of the base of magnetic Chron M18r (Wimbledon et al., 2011) was used to place the Jurassic-Cretaceous (J-K) boundary whereas in the GTS2016, the Jurassic/Cretaceous working group favored a slightly older level in the middle of Chron M19n at the "explosion" of small, globular Calpionella alpina (base of Calpionellid Zone B). Some other studies (e.g., Vennari et al., 2014) proposed a completely different chronostratigraphic model for the base of the Berriasian at $139.55 \pm 0.09$ Ma. More recently, Wimbledon et al. (2020) have proposed the locality of Tré Maroua (Hautes-Alpes, SE France) as a GSSP for the Berriasian stage. However, their work has immediately been criticized by Granier et al. (2020) because the proposed GSSP does not meet at least four of the five geological requirements for a GSSP.

In central Tunisia (Southern Tethys margin), Figure 1A the Lower Cretaceous (Berriasian) stratigraphic record offers a scenic exposure of strata, extremely amenable for stratigraphic investigations. The Sidi Khalif Formation at Jebel Meloussi locality (central Tunisia) is one of the most suitable section for this purpose. Indeed, extensive stratigraphic studies (mainly biostratigraphic investigations) have been widely carried out on this Formation during the last few decades (Burollet, 1956; Memmi, 1967; Busnardo et al., 1976, 1981; Maalaoui and Zargouni, 2016a,b; Ben Nsir et al., 2019) but some of them are controversial (e.g., M'Rabet, 1987; Maalaoui and Zargouni, 2016a; Ben Nsir and Boughdiri, 2017). In this context, several studies (Allen, 1981, 1998; Hallam, 1984, 1985, 1986; Deconinck and Strasser, 1987; Hallam et al., 1991; Deconinck, 1993; Ruffell and Rawson, 1994; Price, 1999) have evidenced the existence of widespread dry and cold climate period during the upper Jurassic. This climatic phase has been followed by a relatively more humid period during the lower Cretaceous (middle to upper Berriasian). Recently, Schnyder et al. (2005) carried out a paleoclimate investigation of the Berriasian stage based on total palynofacies and clay mineralogy from the Sidi Khalif Formation at this locality (Central Tunisia). In their study, Schnyder et al. (2005) reported a major climate change with dry and cool phase, during the late Tithonian to early Berriasian transitioning to a more humid phase in the middle to late Berriasian, indicated by a general increase in kaolinite in the clay mineral assemblages. This trend from a dry climatic phase to a more humid one, is also recorded in higher paleolatitudes, from the boreal area, the northern margin of the Tethys Sea (Deconinck, 1987, 1993; Rasplus et al., 1987; Schnyder, 2003) and also documented southerly in Morocco (Agadir area), on the Atlantic domain (Daoudi et al., 1989; Daoudi and Deconinck, 1994).

In this flopped context of biostratigaphic data, we propose to carry out a cyclostratigraphic study on the Berriasella Jacobi ammonite zone that could help to provide independent data to constrain the duration of this ammonite biozones and thus improve the next GTS (Hinnov and Ogg, 2007). Astrochronology is the field of study (Strasser et al., 2007; Hinnov, 2013) that uses these geologic records of climate rhythms (results of quasiperiodic variations in the Earth's rotation and motion around the sun) to quantify the transit of time from cyclic layers in geologic strata. These climate cycles or the socalled "Milankovitch cycles," are caused by the change in the astronomical parameters of the earth motion in the solar system: the eccentricity $(405,123$, and $95 \mathrm{kyr}$ ), the obliquity (41 kyr) and the precession of the Earth's rotational axis (20 kyr, average precession). Astrochronology provides a direct link between climate oscillations and chronometer which make it a powerful tool in measuring the time through Earth history. Traditional biostratigraphy, magnetostratigraphy and radio-isotopy are often insufficient to yield the rate of geologic mechanisms over short timescale ( $10 \mathrm{kyr}$ ), because of limitations of their accuracy and/or the lack of datable horizons in geologic records. Astrochronology provides a very high-resolution timescale and a strong predictive framework which make it an axial component of integrated stratigraphy (e.g., Aswasereelert et al., 2013; Hilgen et al., 2014; Sageman et al., 2014; Meyers, 2019).

In this study, we used an Astronomical Timescale (ATS) for the lower Sidi Khalif Formation in central Tunisia (Southern Tethys margin). The interval of interest is the basal unit of the Cretaceous outcropping at Jebel Meloussi. Here, we provide an orbital tuning of the sedimentary series from magnetic susceptibility (MS) and calcium carbonate content $\left(\% \mathrm{CaCO}_{3}\right)$ measurements. The obtained ATS is relatively independent of biostratigraphic zones and is not based on subjective counting of marl-limestone couplets, but on a combination of multiple spectral analyses and statistical techniques on the magnetic susceptibility signal.

\section{GEOLOGICAL SETTING}

The studied section belongs to the Jebel Meloussi anticline, which is located in central Tunisia, at $\sim 53 \mathrm{~km}$ south of the city of Sidi Bouzid (Figure 1B). During the Jurassic-Cretaceous transition, the southern margin of the Tethys ocean (Tunisia) is divided into tilted grabens of E-W direction delimiting different paleogeographic domains (Figure 1B). The southern part of this margin corresponds to the Saharan craton, to the Tataouine basin and to the Chotts basin (Figure 1B). The more open marine environments are located further northward in the Central Atlas domain and successively include the platforms of Nara and Zaghouan, followed, to the north, by the Tunisian furrow (Figure 1B). In this paleogeographic setting, the studied section is located at the Jurassic-Cretaceous transition in an intermediate position, between the Wealdian facies in the South and deep marine environments in the North (Figure 1B). This site was selected because it has the advantage of being, proximal enough to the continental detrital input, and thus, sensitive to record climatic variations, but also distal enough to be dated by pelagic faunas and provide an initial timescale for cyclostratigraphic investigations. Furthermore, it is ideal for astrochronology to deal with an interval of continuous sedimentation, which is, indeed, 

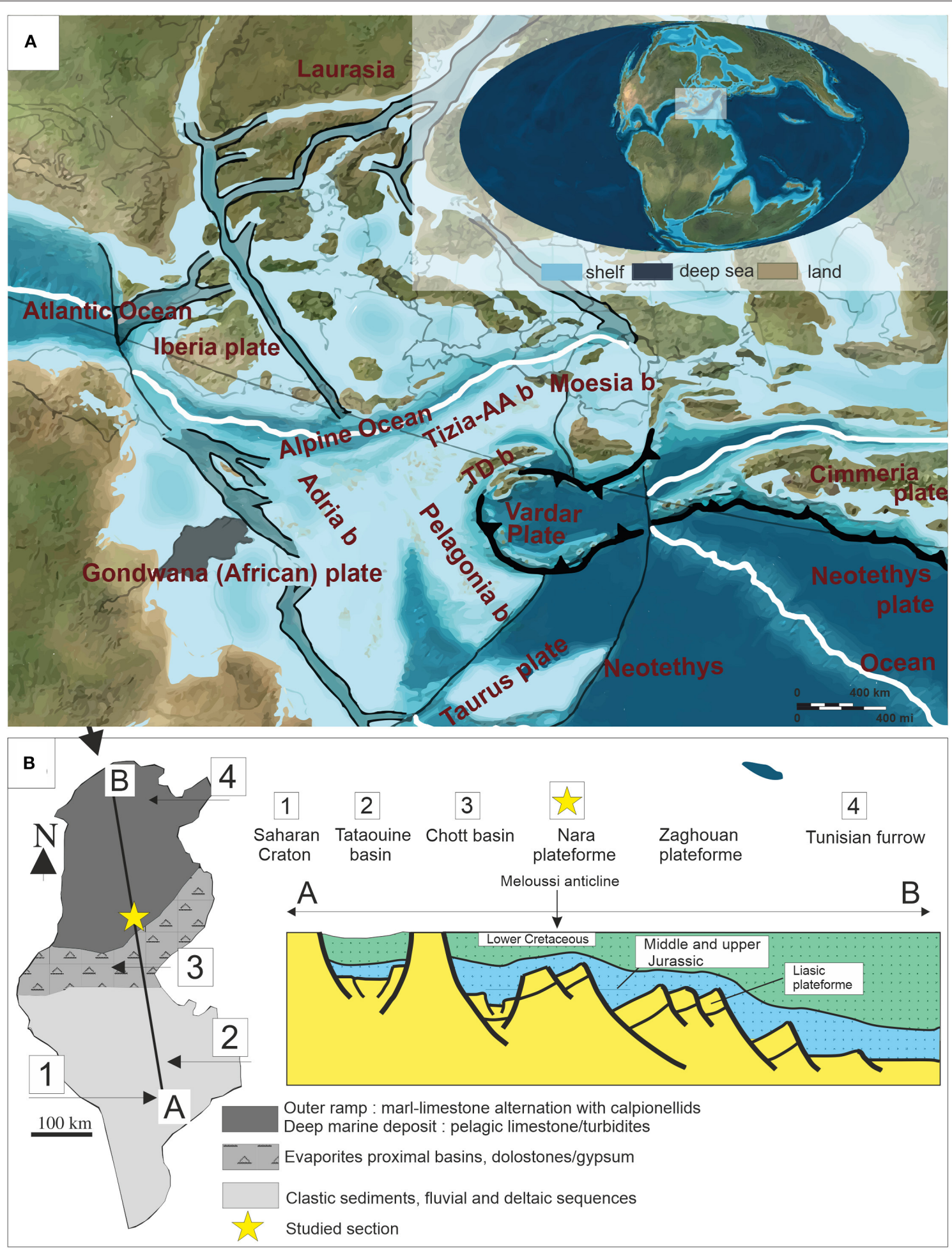

FIGURE 1 | Geologic and geographic setting of the study area. (A) Location of the study area within the Southern Tethys margin during the Late Jurassic (modified after R. Blakey, Colorado Plateau Geosystems, http://cpgeosystems.com/). (B) Late Tithonian paleogeography and facies distribution of Tunisia (modified after Soussi, 2002). The "AB" section shows the Jurassic and Early Cretaceous structural configuration of the Southern Tethys margin (Tunisia). Note the middle position of the Jebel Meloussi outcrop, between the continental saharan craton and the deep marine environments of the "Tunisian furrow" (modified after Soussi, 2002). 
supported by the occurrence of all Calpionella alpine subzones (B1, B2, and B3) (Maalaoui and Zargouni, 2016a) and the absence of any evidence of hiatus, subaerial exposure, erosional features or condensation levels, as revealed by meticulous field observation of sedimentological patterns.

Ammonite and calpionellids biozonations have been first established by M'Rabet $(1981,1987)$ to the Berriasella Jacobi ammonite zone and Calpionallids Zone B, respectively, inferring that this Formation spans the uppermost Tithonian and the entire Berriasian. However, contrasting biostratigraphic hypothesis have been published recently for the Sidi Khalif Formation at Jebel Meloussi by Maalaoui and Zargouni (2016a). The biostratigraphic setting of the Berriasian has been established, but the existence or not of the Tithonian series has been strongly discussed (Ben Nsir and Boughdiri, 2017).

We focus our work on the lower Berriasian (Berriasella Jacobi ammonite zone) which is composed of moderately bioturbated, undisturbed marl-limestone couplets at the base of the section, grayish to greenish marl in the middle part, whereas the upper part consists essentially of limestone (Figures 2, 3). The macrofauna, mainly represented by ammonites, belemnites and occasionally by brachiopods and lamellibranches, irregular echinoids and belemnite guards, is typical of hemipelagic environments, with an estimated water-depth of several hundreds of meters (Hoedemaeker and Leereveld, 1995). The abundance of ammonite specimens and planktonic foraminifera provides the biostratigraphic framework at the zone level (M'Rabet, 1981, 1987) and subzone level (Maalaoui and Zargouni, 2016a). The studied section extends from marls overlaying bed 4 to bed 18 (Figures 2,3), i.e., from the base of Calpionellid Zone B (first appearance datum (FAD) Calpionella alpine after M'Rabet, 1981, 1987) to the base of Subthurmannia Occitanica ammonite zone (M'Rabet, 1981, 1987; Maalaoui and Zargouni, 2016a).

\section{MATERIALS AND METHODS}

\section{Magnetic Susceptibility}

Magnetic susceptibility has been widely used as powerful proxy for paleoclimate investigations (Ellwood et al., 2000; Da Silva et al., 2013; Kodama and Hinnov, 2014). It quantifies the ability of a sample to be magnetized in response to an external magnetic field. This response depends mostly on the amount of magnetic minerals (mostly ferromagnetic and paramagnetic), which are classically carried by detrital inputs. The MS method is widely used by cyclostratigraphers for astronomical calibrations (Mayer and Appel, 1999; Weedon et al., 2004) because it is, reproducible, non-destructive and straightforward to acquire.

A total of 622 samples were collected with an average sampling spacing of $\sim 7 \mathrm{~cm}$ along a $44.45 \mathrm{~m}$ thick section. Low frequency mass specific magnetic susceptibility (MS) measurements were undertaken with a Bartington MS2 magnetometer at the National Engineering School of Sfax (Sfax University). This is a magnetic petrophysical parameter expressed in $\mathrm{kg} / \mathrm{m}^{3}$ and given with a precision of $\pm 8 \times 10^{-10} \mathrm{~m}^{3} / \mathrm{kg}$ ( $95 \%$ confidence level). They are measured under an operating frequency of $0.47 \mathrm{kHz}$ and a $5 \mathrm{~s}$ as a measurement period with the MS2B sensor.

\section{Carbonate Content}

Multiple studies (e.g., Mayer and Appel, 1999; Weedon et al., 2004; Boulila et al., 2008; Martinez et al., 2012) showed that in hemipelagic environments, MS variations are inversely proportional to $\% \mathrm{CaCO}_{3}$ values in hemipelagic environments. This is because the $\mathrm{CaCO}_{3}$ mineral, which is dominant in hemipelagic sediments, dilutes iron-bearing minerals. As a result, $\% \mathrm{CaCO}_{3}$ variations could potentially record the same paleoclimate oscillations as the MS proxy but in an opposite pattern (Martinez et al., 2012, 2020; Martinez, 2018; Hilgen et al., 2020). We used a calibrated Bernard calcimeter to analyze the 622 powdered rock samples for calcium carbonate content. Decalcification was achieved by treating samples with $\mathrm{HCl}(10 \%)$ to remove the calcium carbonate fraction. Reproducibility and quality of the measurements were checked by running duplicate-samples and standards every tenth sample. The precision range varies from 1 to $5 \%$ (Lamas et al., 2005).

\section{X-Ray Fluorescence (XRF) Analysis for Trace and Major Elements}

We analyzed a group of 19 powdered samples (average sampling spacing $=\sim 2.3 \mathrm{~m}$ ) from the studied section, for trace-and major-elements concentration at the GEOGLOB laboratory (Earth Sciences Department of Faculty of Sciences of Sfax, Sfax University, Tunisia). Geochemical study was realized by X-rays fluorescence XRF with Thermo scientific device Niton FXL FMXRF Analyzer. This method is used in order to determine chemical elements that constitute the bulk rock.

\section{Time Series Analysis}

In this section, we present the step-by-step methodology for the detection and interpretation of potential Milankovitch cycles in the $\mathrm{MS}$ and $\% \mathrm{CaCO}_{3}$ records to construct a floating astronomical time scale (ATS). Because paleoclimate parameters may have different responses to orbital forcing (Li et al., 2019b; Ma et al., 2019; Sinnesael et al., 2019), relying on one single proxy could affect the reliability of the ultimate inferred astronomical timescale. Therefore, we choose to implement the results of spectral analysis of two paleoclimate proxies (MS and \% $\mathrm{CaCO} 3$ ). Spectral analysis was performed on a MATLAB platform using Acycle v2.2 software (Li et al., 2019a):

1) Prior to any analysis, the $\mathrm{MS}$ and $\% \mathrm{CaCO}_{3}$ data were interpolated linearly at $7 \mathrm{~cm}$ intervals (average sampling spacing). We removed long-term trends by running the "smooth" MATLAB script using a moving-average window of 217 points (35\% LOWESS).

2) Cyclicities were estimated using the Multi-taper Method

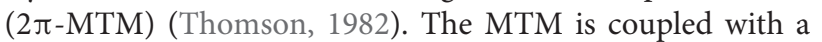
classical red noise model following the Husson's "redconf.m" MATLAB script (Husson, 2014). Afterwards, we applied the frequency ratios method (Huang et al., 1993; Boulila et al., 2008) (Tables 1, 2 and Figure 5) which serves as a preliminary test for the existing of astronomical frequencies in the MS and $\% \mathrm{CaCO}_{3}$ stratigraphic series. In addition, we performed two independent evolutionary spectrograms using two different 


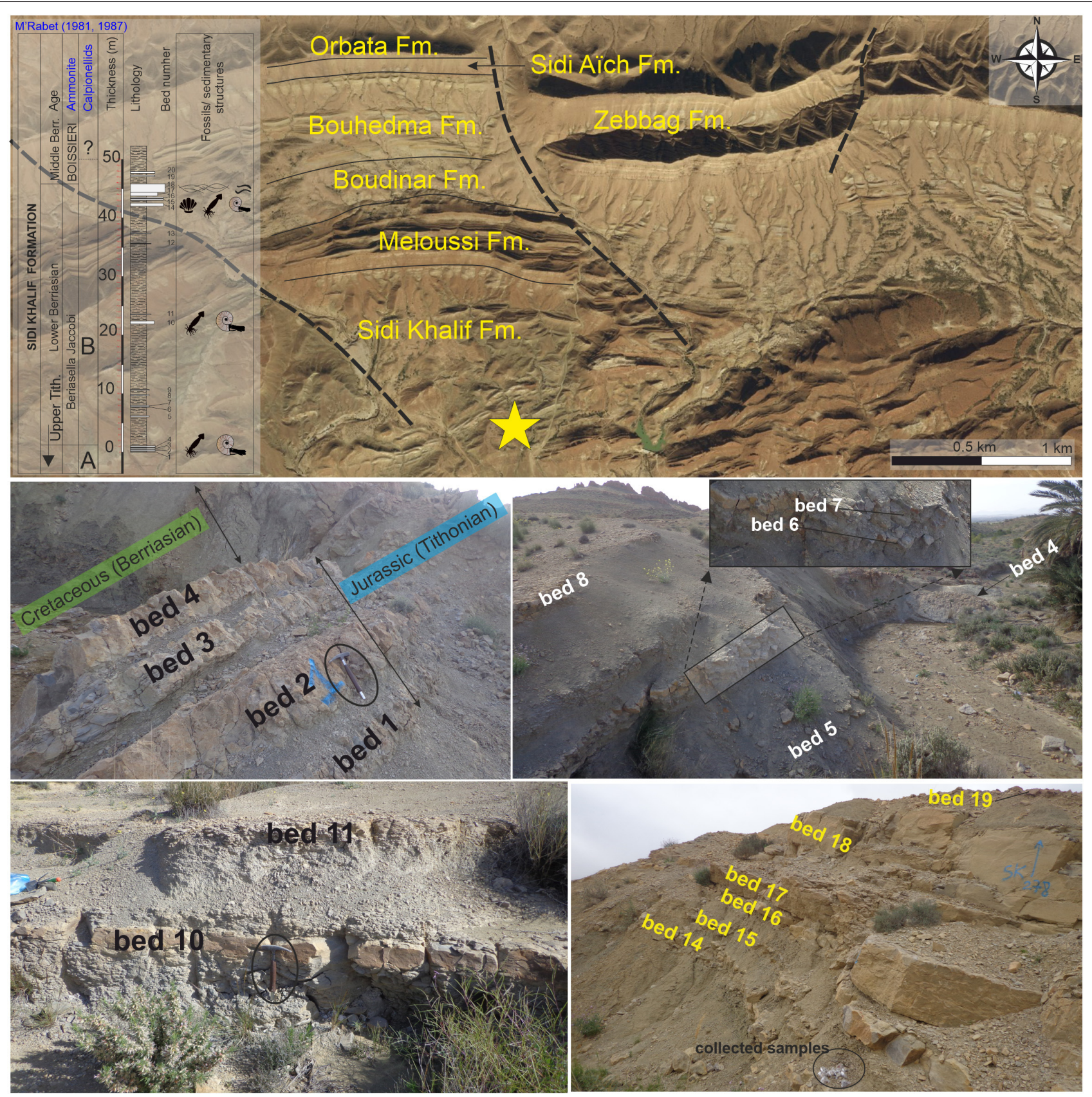

FIGURE 2 | Outcrop photos of beds 1-19 along the sedimentary succession of the studied interval. The top figure shows the outcropping Formations in the study area. The yellow star represents the location of the studied section.

methods which are the Evolutionary Fast Fourier Transform (evoFFT) performed using the "evofft.m" MATLAB script of Kodama and Hinnov (2014) and the Continuous Wavelet Transform (CWT) (Torrence and Compo, 1998) executed using the "Wavelet Transform" function in Acycle v2.2 software. The evoFFT and CWT techniques serve to assess the evolution of astronomical components in both proxies and to track the sediment accumulation rate variations along the studied section.
3) Prominent orbital cycles (in the stratigraphic domain) were extracted by band-pass filtering using the Taner filter (Taner, 2000) of the "Filtering" function in Acycle v2.2. Based on the interpreted "E" (long orbital eccentricity) cycles, we carried out a "minimal tuning with linear interpolation" (Muller and MacDonald, 2000) using depthtotime.m. function under Acycle software.

4) The resulting tuned signal was interpolated to a uniform sampling spacing based on the original sample rates. MTM 


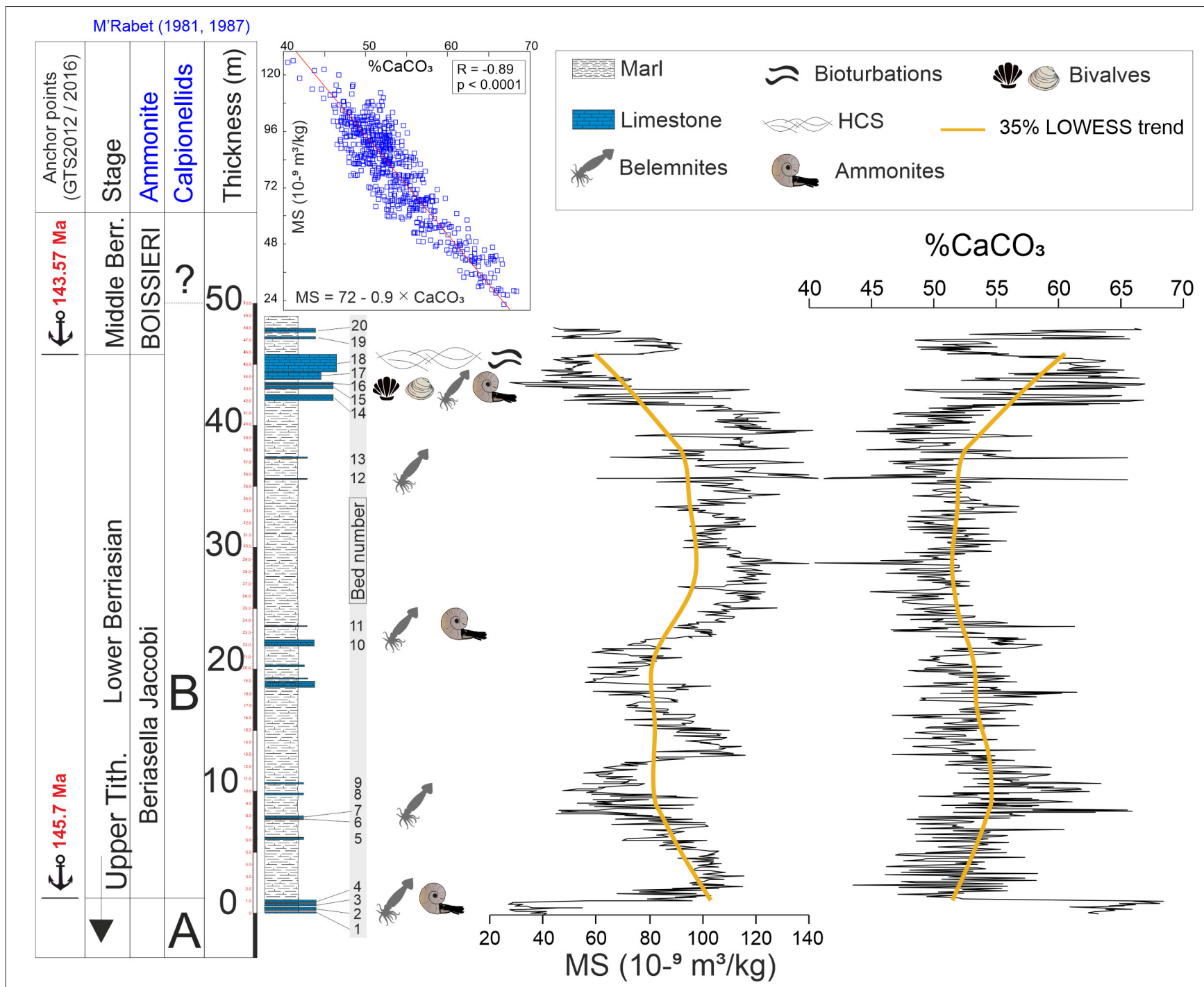

FIGURE 3 | Variations of the used proxies through the studied interval with a 35\%LOWESS detrend (thick yellow line). The top left graph shows the linear model of the $M S$ vs. $\% \mathrm{CaCO}_{3} ; \mathrm{R}=-0.89$.

spectral analysis with harmonic F-testing and Evolutionary power spectra as performed in Step 2 were applied on the newly tuned time-series.

5) Evolutionary power spectra and the MTM spectral analysis with harmonic F-testing as in Step 2 were applied on the newly constructed time-series.

\section{Modeling of Sediment Accumulation Rate (SAR)}

The changes in SAR are generally problematic for cyclostratigraphy and to depict potential orbital cycles from the analyzed stratigraphic series. All SARs inferred in this study are post compaction. To obtain a meaningful interpretation of the variation in SAR, we applied three independent methods on the Sidi Khalif MS stratigraphic series: a) Correlation coefficient (COCO) method ( $\mathrm{Li}$ et al., 2018b), which works in the same way as the frequency ratio method, calculates the coefficient of correlation between the frequencies of power spectra of a given stratigraphic proxy series and an astronomical solution in a given time interval of the GTS, ranging between a minimal and maximal sedimentation rates. To determine this threshold of SARs, we relied on relative ages offered by both Maalaoui and Zargouni (2016a) and M’Rabet (1981, 1987) biostratigraphic models. According to these, average SAR should be around 2-3 cm/kyr. Thus, reasonable SARs was estimated to range between 1 and $5 \mathrm{~cm} / \mathrm{kyr}$ for the lower Sidi Khalif Formation. To track changes in the SAR along the studied stratigraphic series, we used the evolutionary correlation coefficient method (eCOCO) (Li et al., 2018b). This method allows to calculate the coefficients of correlation between 
TABLE 1 | Stratigraphic positions, floating geochronology, and anchor points used to build the age model used in this study.

\begin{tabular}{lccc}
\hline $\begin{array}{l}\text { 405 kyr } \\
\text { maxima/minima }\end{array}$ & $\begin{array}{c}\text { Stratigraphic } \\
\text { position }(\mathbf{m})\end{array}$ & $\begin{array}{c}\text { Floating } \\
\text { time (kyr) }\end{array}$ & $\begin{array}{c}\text { La2004 } \\
\text { time (ka) }\end{array}$ \\
\hline $\mathrm{E}_{405}$ 1 maxima & 4.05 & 0 & 145,095 \\
$\mathrm{E}_{405} 1$ minima & 9.62 & 157 & 144,859 \\
$\mathrm{E}_{405} 2$ minima & 15.02 & 360 & 144,657 \\
$\mathrm{E}_{405} 2$ maxima & 20.79 & 570 & 144,454 \\
$\mathrm{E}_{405} 3$ minima & 26.47 & 775 & 144,252 \\
$\mathrm{E}_{405} 3$ maxima & 32.40 & 1,180 & 144,051 \\
$\mathrm{E}_{405} 4$ minima & 38.71 & 1,385 & 143,841 \\
$\mathrm{E}_{405} 4$ maxima & 44.47 & 1,590 & 143,610 \\
\hline
\end{tabular}

MS series was tuned to the orbital 405 kyr eccentricity solution of La2004.

TABLE 2 | Summary of sedimentation rates and durations calculated by the different used methods (see Methods, section Astronomical Target Curve).

\begin{tabular}{lccccc}
\hline Method & $\begin{array}{l}\text { Average sediment accumulation } \\
\text { rates (cm/kyr) }\end{array}$ & & & $\begin{array}{r}\text { Duration } \\
\text { estimate } \\
\mathbf{( k y r )}\end{array}$ \\
\hline COCO & 1.3 & & $\mathbf{2 . 8 3}$ & - & 1,570 \\
TimeOpt & 1.65 & 2.37 & $\mathbf{2 . 9 5}$ & 4.5 & 1,506 \\
ASM & - & $\mathbf{2 . 2 5}$ & - & - & 1,972 \\
Frequency ratios & - & $\mathbf{2 . 4 6}$ & - & - & 1,800 \\
Orbital Tuning & - & - & $\mathbf{2 . 7 9}$ & - & 1,590 \\
(E405 cycle & & & & & \\
counting) & & & & & \\
\hline
\end{tabular}

The optimal SAR estimated by each method is highlighted in bold.

the power spectra of a paleoclimatic proxy series and its corresponding associated astronomical forcing series within a sliding window, then convert the proxy series from a depth domain to time domain to acquire the variation of SAR (Kodama and Hinnov, 2015; Li et al., 2016a,b, 2018b). The MS series is linearly interpolated to an average sampling interval $(7 \mathrm{~cm})$ and detrended by removing a $35 \%(15.55 \mathrm{~m})$ rloess trend, and then the eCOCO method is applied for a range of SARs between 1 and $5 \mathrm{~cm} / \mathrm{kyr}$. We performed 5,000 Monte Carlo simulations to calculate both the COCO and eCOCO.

b) Time Optimization (TimeOpt) (Meyers, 2015) and evolutive Time Optimization (eTimeOpt) (Meyers, 2019) analysis evaluates orbital eccentricity-like variations in the data, together with supporting evidence from amplitude modulations of the precession index band, upon a test range of SARs (Meyers, 2015, 2019), which in this case are similar to those selected for eCOCO (1-5 cm/kyr). Additionally, we assessed the statistical significance of the TimeOpt analyses results by performing Monte Carlo AR1 model simulations (Meyers and Malinverno, 2018) under Acycle software (TimeOptSim function). The original TimeOpt analyses (Meyers, 2015, 2019) utilizes a constant SAR model which is often applicable for relatively short stratigraphic record deposited in deep-sea environments. However, it can be problematic over longer time scales, and is less likely to be valid in more proximal shelf and continental realms (Meyers, 2019). We outlined in section Geological Setting that our section is a hemi-pelagic sedimentary succession type, and spans over $\sim 2$ Myr-duration of sedimentation, which lead us to consider it amenable for such statistical analysis. If the SAR is indeed changing along the section, the application of the evolutive Time Optimization (eTimeOpt) method can overcome such problem and allow to reconstruct the vertical change the SAR.

c) Meyers and Sageman (2007) developed the Average Spectral Misfit (ASM) technique which compares the spatial frequencies (in depth domain) with the astronomical frequencies of the same age, then calculates an optimal SAR that matches the best astronomical fit. This SAR (in $\mathrm{cm} / \mathrm{kyr}$ ) is statistically assessed by estimating the highest confidence level and, furthermore, by performing a test for rejection of Null Hypothesis of no orbital forcing $\left(\mathrm{H}_{0}-\mathrm{SL}\right)$. We used the target orbital frequencies of Laskar et al. (2004) to perform the ASM analysis.

\section{Astronomical Target Curve}

The earth orbital parameters obliquity and precession cannot be calculated accurately before to the Cenozoic times because of the chaotic behavior of the solar system over time. The earth orbital long eccentricity ( $405 \mathrm{kyr}$ ) cycle is the most stable orbital parameter throughout the Phanerozoic that can be used as a metronome for reconstructing reliable ATS prior to the Cenozoic (Laskar et al., 2004; Kent et al., 2018). The La2004 and La2010 astronomical solutions are available for ages older than 42 and $50 \mathrm{Ma}$, respectively (Laskar et al., 2004, 2011). The La2010d (Laskar et al., 2011) can be used to represent the most reasonable astronomical solution for ages older than $54 \mathrm{Ma}$. However, Liu et al. (2020) showed that La2004 solution (Laskar et al., 2004) is valid much further back in time than is currently recognized.

\section{Modeling of the Sea-Level-Change: DYNOT and $\rho 1$ Noise Models}

The "DYNOT" (Dynamic Noise after Orbital Tuning) model was designed by $\mathrm{Li}$ et al. (2018a) to measure noise in climate and sea-level proxies. If proxy-related noise and other contributing factors (e.g., tectonics, bioturbation, volcanism, and sub-Milankovitch cycles) are minor, the variance of the noise can be an indicator for relative sea-level changes. For a $10^{3}$ to $10^{6}$ year-band in the power spectra of proxy series, this technique evaluates the ratio of non-orbital signal variance to the total variance, which is calculated along a sliding time window. When sea-level is relatively high, the DYNOT ratio is weaker than the ratio in a time of relatively low sea-level, and vice versa. The DYNOT model was performed using the Acycle v2.2. software.

In addition to the DYNOT model, Li et al. (2018a) designed the $\rho 1$ sea-level model as a second, independent noise indicator for relative sea-level change. The authors demonstrated that increased noise leads to a decreased $\rho 1$ value, and vice versa. 


\section{MS AND $\% \mathrm{CACO}_{3}$ RECORDS}

MS values range from $22.4 \times 10^{-9}$ to $126.0 \times 10^{-9} \mathrm{~m}^{3} / \mathrm{kg}$ and the $\% \mathrm{CaCO}_{3}$ ranges from 40.5 to $68.4 \%$ along the section. As anticipated, limestone beds show lower MS values than the interbedded marls. MS and $\% \mathrm{CaCO}_{3}$ values show a significant negative correlation $(\mathrm{R}=-0.89, p<0.001$; top left graph in Figure 3), indicating that MS variation is mainly controlled by the lithology, as well-known for pelagic series (e.g., Mayer and Appel, 1999; Boulila et al., 2008). Moreover, this negative correlation is well-documented by the antagonist evolutionary pattern of 211 points Gaussian-weighted moving average (35\% LOWESS) applied to the both MS and $\% \mathrm{CaCO}_{3}$ (yellow thick lines in Figure 3).

Magnetic susceptibility measurements are being classically used as proxy for climatic and eustatic variation (Da Silva et al., 2013; Kodama and Hinnov, 2014; De Vleeschouwer et al., 2015). The oscillations of Milankovitch cycles affect the amount of solar energy received by the Earth surface on different temporal and spatial scales, which influence, consequently, climatic conditions (dry and humid phases) and, thus, control the detrital input a to the basin. Ultimately, this complex interaction between orbital and climatic process is reflected by the MS variations along the analyzed stratigraphic record (De Vleeschouwer et al., 2015).

However, MS signal in Mesozoic sedimentary series is vulnerable to post-depositional distortion such as diagenesis processes and metamorphism which affect the primary depositional environmental and climatic information (Riquier et al., 2010; Da Silva et al., 2013). To test the reliability of the MS preservation into the analyzed samples, we measured trace-element proxies for detrital input $(\mathrm{Ti}, \mathrm{Rb}, \mathrm{Al}$, and $\mathrm{Zr}$; Calvert and Pedersen, 2007; De Vleeschouwer et al., 2015) and those geochemical results were compared with MS results for the entire section (Figure 4). The evolution of MS series and these terrestrial input proxies follows parallel large-scale trends and show fair to good correlation $(r=0.71-0.73 ; N=19)$ (Figure 4). Therefore, we assume that diagenesis/remagnetization did not significantly biased the original paleoenvironmental and paleoclimatic information (Riquier et al., 2010).

Moreover, Schnyder et al. (2005) carried out a multidisciplinary study for paleoclimatic investigation on the Berriasian sedimentary series at Jebel Meloussi and reported that no significant diagenesis imprint has been found on the lower Berriasian (Berriasella Jacobi zone, this section). According to the authors, the only few traces of possible diagenesis occur in the middle Berriasian (Subthurmania Occitanica Zone) which fall utterly out of our interval of interest.

\section{Cyclostratigraphic Analysis}

Spectral analysis of the $\sim 44 \mathrm{~m}$ succession of $\mathrm{MS}$ and $\% \mathrm{CaCO}_{3}$ records show prominent peaks at $\sim 10,2.2,0.87,0.66,0.57,0.43$, and $0.34 \mathrm{~m}$ with high confidence level values often exceeding 0.9 (Figure 5). To interpret these peaks in terms of possible orbital periods, we calculated, as a preliminary test, their ratios (Supplementary Table 2) and compared them to orbital period ratios relative to the Berriasian stage (Laskar et al., 2004)
(Supplementary Table 1) following the frequency ratio method. Spectral period ratios are very close to orbital period ratios with a rather high correlation coefficient of 0.98 and 0.97 for the $\mathrm{MS}$ and $\% \mathrm{CaCO}_{3}$ signals, respectively (Figure 5). Hence, we accordingly attribute these peaks to the long eccentricity (405 kyr), the short eccentricity (100 kyr), the obliquity $(45,36$, and $27 \mathrm{kyr}$ ) and the precession (22 and $18 \mathrm{kyr}$ ), respectively. This method of frequency ratios indicates an average SAR of $\sim 2.46 \mathrm{~cm} / \mathrm{kyr}$. To better ensure the validity of the interpreted Milankovitch cycles in depth domain, we applied the protocol described by Kodama (2019) on the untuned MS series to see whether precession cycles are modulated by short eccentricity cycles. First, we filtered the untuned MS series at a bandwidth frequency that we assume to be the precession cycles (22-18 kyr). Then, we performed an amplitude modulation (AM) test on the obtained output filter (red curve in Supplementary Figure 1A, corresponding to short eccentricity cycles modulating the precession cycles) which are grouped into sets of 4-6 precession cycles. Finally, we ran $2 \pi-$ MTM on the amplitude envelope of the filtered series and found strong peaks among which the short eccentricity band is significantly highlighted above the 99\% CL (Supplementary Figure 1B). Therefore, we can claim that the interpreted short eccentricity and precession cycles are well-selected in the MTM power spectra of Figure 5.

The long eccentricity (405 kyr) displays the strongest amplitude in the global power spectrum and the $2 \pi-\mathrm{MTM}$ and their corresponding evolutionary tests (CWT and evoFFT) (Figures 6A,D). For both proxies, the continuous wavelet analysis reveals parallel bands with cycle lengths of 11-9, 2.4-2.1, and 1.14-0.9 $\mathrm{m}$ (Figures 6A,D). The evolutionary FFT spectrograms of the untuned $\mathrm{MS}$ and $\% \mathrm{CaCO}_{3}$ series show variations in the cycle lengths vs. the thickness (Figures 6B,C) which may be due to a change in the SAR. As expected, highestpower cycles revealed by the MTM analysis display continuous lines in the EHA analysis. For the MS proxy, the interpreted $\mathrm{E}_{405}$ cycle is dominant for the entire section but its power is dampened at ca. 33-40 $\mathrm{m}$ at the expense of the $\mathrm{e}_{100}$ amplitude (Figure 6B). The $\% \mathrm{CaCO}_{3}$ proxy exhibits mirrored pattern as the MS proxy for both "E" and " $\mathrm{E}$ " cycles. The only exception is the bifurcation into high-amplitude period at $8.6 \mathrm{~m}$ and lowamplitude period at $11.7 \mathrm{~m}$ occurring over the 33-40 $\mathrm{m}$ interval. Such bifurcations could reflect intervals of hiatuses or amplitude modulations (Meyers et al., 2001; Meyers and Sageman, 2004). Also, strong condensation or obliquity/precession recorded while the sedimentation rate decreases can lead to this pattern. Hiatuses are unlikely due to the absence of hardgrounds, subaerial exposure, glauconitic or phosphatic levels.

Because the spectral power of the obliquity and precession cycles are much lower than that of the long eccentricity, it is hard to recognize it on the EHA spectra, in particular for the MS series where the strongly expressed $\mathrm{E}_{405}$ cycles hinder the discrimination of any other potential orbital frequencies. Thus, recognition of the obliquity and precession is primarily based on the relative scale of their spectral power on the spectrogram of amplitudes. To overcome this issue, we performed EHA analysis on each astronomical frequency independently (Figure 10). The purpose is to examine all Milankovitch cycles with better visibility 


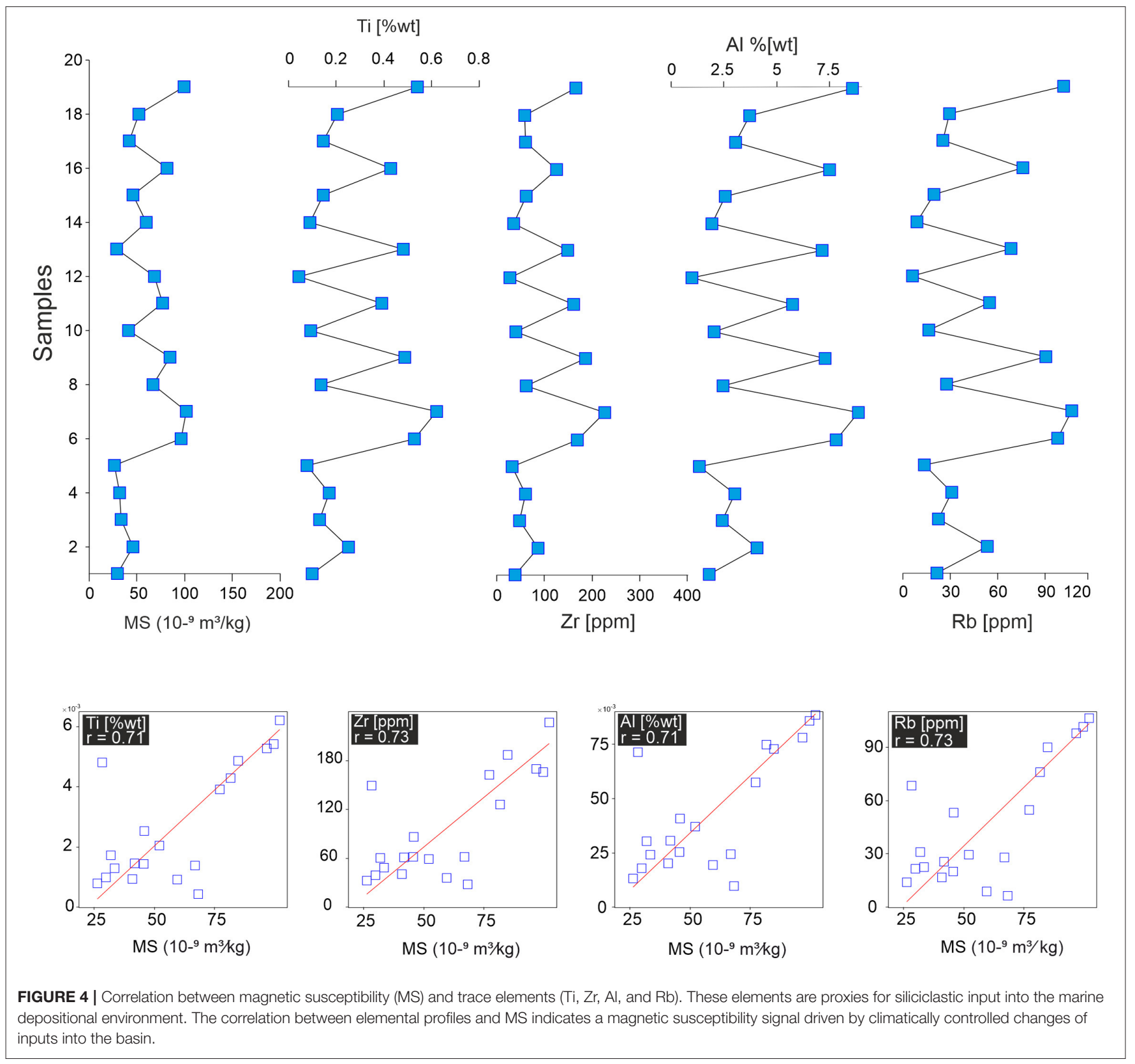

and interpret their variations in terms of change in SAR (detailed later in section Variations of the Sediment Accumulation Rate).

\section{Tracking the Sediment Accumulation Rates Evolutionary Coefficient of Correlation (eCOCO)}

COCO was applied to identify the most likely SAR along the record. The COCO analysis shows one main maxima of stable $\mathrm{SAR}$ at $2.83 \mathrm{~cm} / \mathrm{kyr}$ with a correlation coefficient value exceeding 0.45 (Figure 7). Another secondary maximum arises at 1.2 $\mathrm{cm} / \mathrm{kyr}$. Both SAR values have a null hypothesis values $\left(\mathrm{H}_{0}\right.$, no orbital forcing) lower than the $0.1 \%$ (Figure 7) and seven astronomical parameters involved in the estimation. The results of eCOCO analysis (which is evolutive) unravel the history of the
SARs variations along the Sidi Khalif Formation. Three distinct portions of record with changing sedimentation rate are visible (Figure 7, top-right graphs) starting by a relatively stable SAR at $\sim 2.2 \mathrm{~cm} / \mathrm{kyr}(1-16 \mathrm{~m})$, followed by an increasing trend with the SAR reaching $\sim 3 \mathrm{~cm} / \mathrm{kyr}$ between ca. $16-34 \mathrm{~m}$. The rest of the section has a mean SAR of $1.5-1.7 \mathrm{~cm} / \mathrm{kyr}$.

\section{Evolutionary Time Optimization (eTimeOpt)}

TimeOpt analysis (Supplementary Figures 2G-I) indicates an $\mathrm{r}_{\mathrm{opt}}^{2}$ maximum at a SAR of $2.95 \mathrm{~cm} / \mathrm{kyr}$, for which TimeOptSim analysis estimates a quite low $p$-value of 0.05776 (Supplementary Figure 2I). This SAR is close to the $2.83 \mathrm{~cm} / \mathrm{kyr}$ SAR obtained by the COCO analysis (see above). The $\mathrm{r}_{\text {envelope }}^{2}$ 


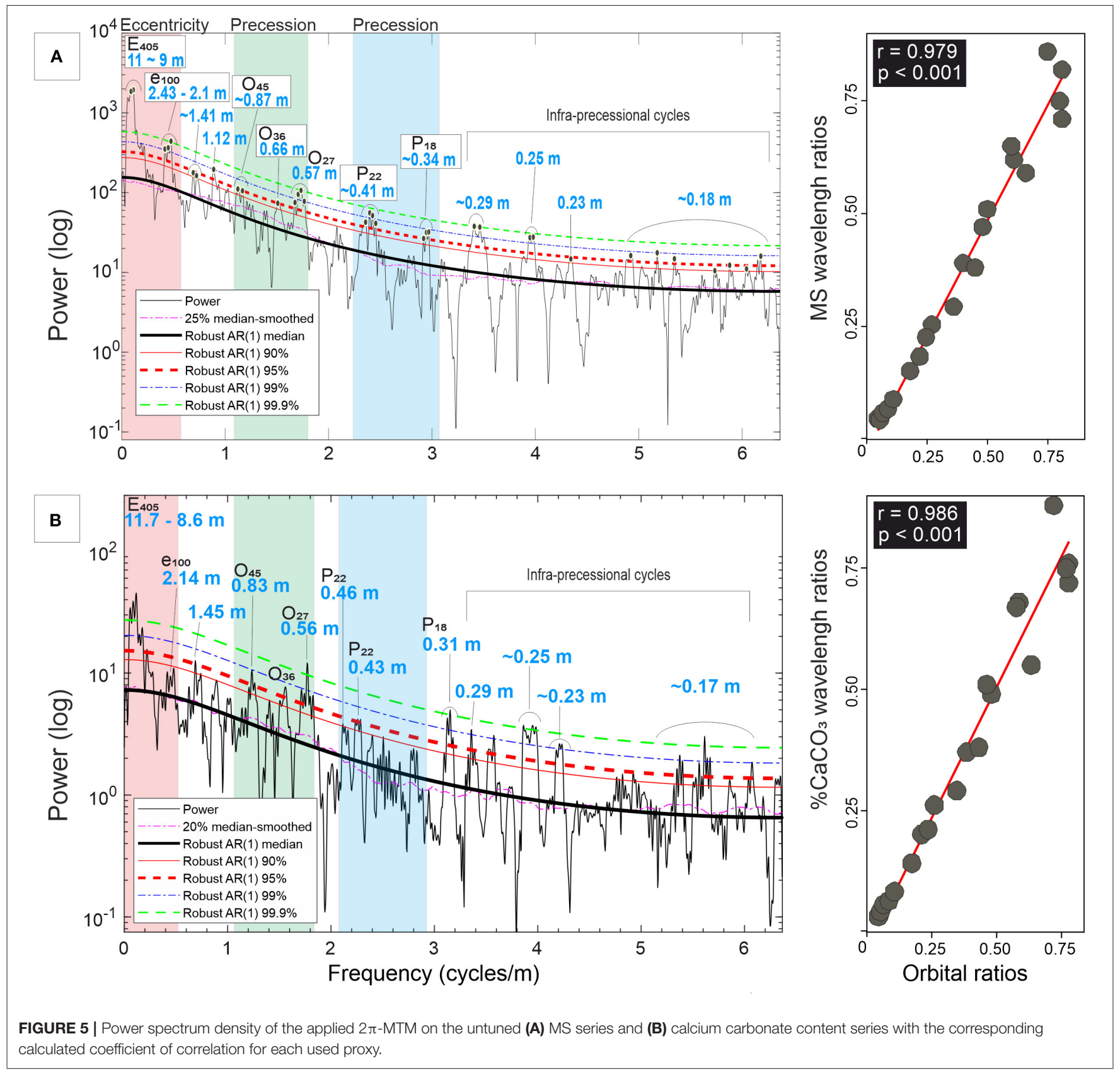

assessment (Supplementary Figure 2C) indicates a much faster SAR at ca. $4.5 \mathrm{~cm} / \mathrm{kyr}$ but with a higher $p$-value of 0.56668 (Supplementary Figure 2J); $r_{\text {power }}^{2}$ (Supplementary Figure 2K) indicates $\sim 2.7 \mathrm{~cm} / \mathrm{kyr}$, a closer value to those revealed by COCO and ASM techniques, and with an extremely low $p$ value of 0.00358 (Supplementary Figure 2K). Adopting 2.95 $\mathrm{cm} / \mathrm{kyr}$ as the optimal SAR leads to a periodogram of the MS series with a strong orbital long eccentricity signature (Supplementary Figure 2F).

Similarly, to the eCOCO, the eTimeOpt analysis (Supplementary Figures 2G-I) suggest long-term changes in average SAR. The sedimentation history is most unambiguously resolved in the spectral power fit $\left(\mathrm{r}_{\text {power }}^{2}\right)$, and the combined envelope and spectral power fit $\left(\mathrm{r}_{\text {opt }}^{2}\right)$, identifying three sedimentation rate regimes (Supplementary Figures 2G-I): (1) a region of relatively stable sedimentation (1-21 m) with an average sedimentation rate of $\sim 2 \mathrm{~cm} / \mathrm{kyr}$, presenting two emerging peaks of SAR at $\sim 3.8 \mathrm{~cm} / \mathrm{kyr}$, (2) a higher sedimentation interval from $\sim 21$ meters to $\sim 37$ meters (SAR ranges between $\sim 2$ and $\sim 4 \mathrm{~cm} / \mathrm{kyr}$ ), and (3) a progressive decline in sedimentation rates for the rest of the section (average sedimentation rate $=\sim 1.7 \mathrm{~cm} / \mathrm{kyr}$ ). 

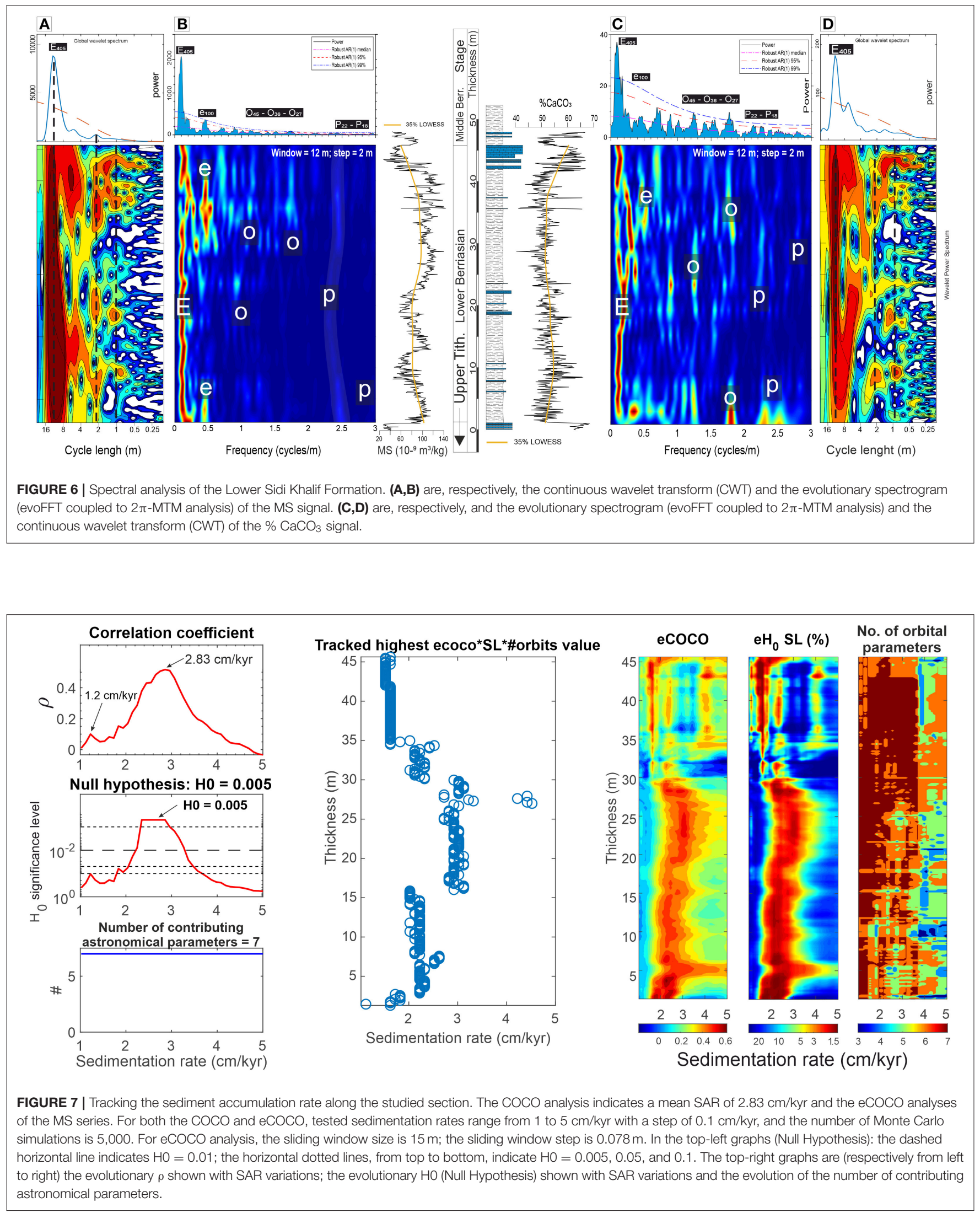


\section{Average Spectral Misfit (ASM)}

ASM analysis for the MS series indicates a statistically significant $(\mathrm{H} 0=0.09 \%$, Supplementary Figure 3C) solution at 2.25 $\mathrm{cm} / \mathrm{kyr}$ (Supplementary Figure 3A). Seven of the totals of eight astronomical target frequencies were evaluated for this result (Supplementary Figure 3B), excluding only the precession at $25 \mathrm{kyr}$ as indicated by one black vertical dashed line that do not coincide with any of the vertical red lines (Supplementary Figure 3D).

\section{Orbital Tuning}

In this study, we compared both tuning on La2010d and La2004 solutions and it appears that the latter fits much better our initial timescale (biostratigraphy of M'Rabet, 1981, 1987). Hence, the Milankovitch cycles identified in the lower Sidi Khalif Formation can be tuned using the target curve filtered from the theoretical astronomical solution of La2004 (Laskar et al., 2004) (Figure 8). The untuned 405-kyr-filtered $\mathrm{MS}$ and $\% \mathrm{CaCO}_{3}$ series show a strong negative correlation, which indicates that both proxies can be calibrated by La2004 astronomical solutions. Four 405-kyr long eccentricity cycles $\left(\mathrm{E}_{405} 1\right.$ to $\mathrm{E}_{405} 4$ in Figure 8) extracted from the MS series were compared to the theoretical target curve of La2004 astronomical solution between 145.7 and $143.57 \mathrm{Ma}$. Astronomical tuning was further completed by assigning the long eccentricity peaks of the MS series to the 405 kyr filtering peaks of the La2004 astronomical solution (Figure 8). The tuning quality is assessed to be good (for $\mathrm{E}_{405} 1$ and $\mathrm{E}_{405} 2$ ) to fair (for $\mathrm{E}_{405} 3$ and $\mathrm{E}_{405} 4$ ) (Figure 8). Minima of the filtered $405 \mathrm{kyr}$ cycles of La2004 astronomical solution match well the MS minima along the entire tuned interval (Figure 8) which support more the quality of the tuning. This tuning proposes that our section spans an interval of 1.6 Myr from 145.3 to $143.57 \mathrm{Ma}$ (see Table 1 for anchor points). The appearance of the $\sim 200 \mathrm{kyr}$ cycle on the MTM power spectra of both tuned MS and \% $\mathrm{CaCO}_{3}$ series (Figure 8) is interesting. Indeed, this cycle has been recently found by Hilgen et al. (2020) and explained as the expression of alternating distinct and less distinct $\sim 100$-kyr $\mathrm{CaCO}_{3}$ maxima and associated magnetic susceptibility (MS) minima, which correspond to successive minima of the short $\sim 100$-kyr eccentricity cycle. This observed cycle, which is different than the $173 \mathrm{kyr}$ obliquity cycle, does not represent an artificial harmonic of the $405 \mathrm{kyr}$ cycle, nor a double $\sim 100 \mathrm{kyr}$ cycle. These authors interpreted it to reflect a real but weakened and complex eccentricity component beside the principal eccentricity cycles.

\section{DISCUSSION}

\section{Astrochronology of the Lower Sidi Khalif Formation}

We implemented different methods to calculate the average SAR along the section. A summary of all obtained SARs is presented in Table 2. The TimeOpt, ASM and the frequency ratios methods showed three close values of SAR at 2.37, 2.25, and $2.46 \mathrm{~cm} / \mathrm{kyr}$, respectively. Also, a range of SAR between 2.83 and $2.952 \mathrm{~cm} / \mathrm{kyr}$ is shared between the COCO and the TimeOpt (Table 2). Each method permitted to estimate a total duration for the section which are highlighted in Table 2.

In addition, we extracted the $\mathrm{E}_{405} \mathrm{kyr}$ and $\mathrm{e}_{100} \mathrm{kyr}$ cycles from the tuned MS signal and filtered them using Taner filter (Taner, 2000). We, afterward, simply counted the total number of long- and short-eccentricity cycles (405 kyr) along the entire section, which pointed to a number of four complete cycles (Figure 8). This allowed us to construct a floating timescale of a duration of $\sim 1.6 \mathrm{Myr}$ for the studied interval giving, an average SAR of $2.75 \mathrm{~cm} / \mathrm{kyr}$ (Table 2), which solution was obtained through three methods of SAR calculation [1,570 kyr (COCO), 1,506 kyr (TimeOpt), and 1,590 kyr (counting of E405 cycles), see Table 2]. Based on the biostratigraphy developed by M'Rabet $(1981,1987)$, initial sedimentation of the studied section began at $145.7 \mathrm{Ma}$ (FAD of Calpionella alpine Zone B), and deposition ended at 143.53 Ma (FAD of Subthurmania Occitanica ammonite zone) (according to GTS2012; Gradstein, 2012; Ogg et al., 2012 and GTS2016). This age constraint suggests a total duration of $2.17 \mathrm{Myr}$ for the section with an average SAR of $2.04 \mathrm{~cm} / \mathrm{kyr}$. However, as mentioned in the geologic setting (section Geological Setting), this biostratigraphic setting is controversial with Maalaoui and Zargouni (2016a) who reported that the calpionellids Zone A does not exist in the section, i.e., the section does not cover any Jurassic sedimentary series at Jebel Meloussi locality. The only common stratigraphic point which is not problematic between the two authors is the Berriasella Jacobi-Subthurmania Occitanica (Lower Berriasian-Middle Berriasian) boundary, which we refer to it as a tie point for our floating ATS revealed by the 405 kyr-filter output of the tuned MS series. The duration obtained by M'Rabet; M'Rabet (1981; 1987; $2.17 \mathrm{Myr}$ ) is longer than our estimate $(\sim 1.6 \mathrm{Myr})$. However, our estimate is in better agreement with the chronostratigraphy proposed by Maalaoui and Zargouni (2016a). To conclude, our proposed floating ATS points to a duration of 1.6 Myr for the studied interval and are supportive of the biostratigraphy of Maalaoui and Zargouni (2016a).

\section{Reliability of the Used Proxies}

For the few recent decades, magnetic susceptibility measurement is being used as a proxy for climatic and eustatic variation (Da Silva et al., 2013; Kodama and Hinnov, 2014; De Vleeschouwer et al., 2015). The oscillations of Milankovitch cycles affect the amount of solar energy received by the Earth surface on different temporal and spatial scales, which influence, consequently, climatic conditions (dry and humid phases) and, thus, control the detrital input a to the basin. Ultimately, this complex interaction between orbital and climatic process is reflected by the MS variations along the analyzed stratigraphic record.

To better explain the link between the MS fluctuations and cyclostratigraphy, we propose the following plausible flow of explanations:

Some paramagnetic minerals (e.g., illite, smectite, and chlorite) are endogenous in origin, which means that their delivery to sedimentary basins must be ensured first by the erosion of preexisting rocks. continental weathering can 

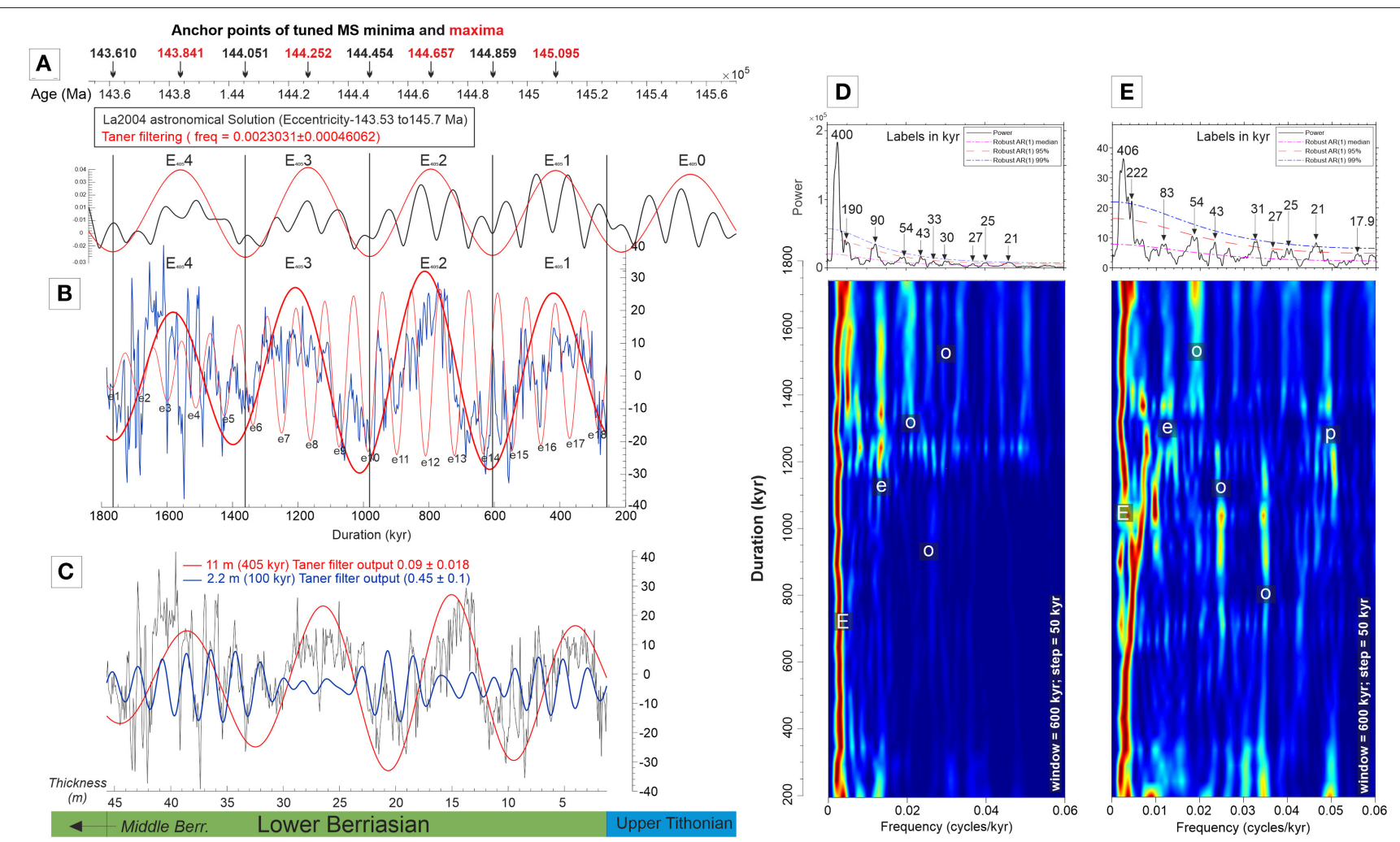

FIGURE 8 | Orbital tuning of the MS series at Jebel Meloussi locality, and geochronology of the lower Sidi Khalif Formation. (A) 405 kyr filter output of the La2004 astronomical solution (from 145.53 to $145.7 \mathrm{Ma}$ ). (B) 405 and $100 \mathrm{kyr}$ filter output of the tuned MS stratigraphic series. Duration estimate points to 1.6 Myr with a

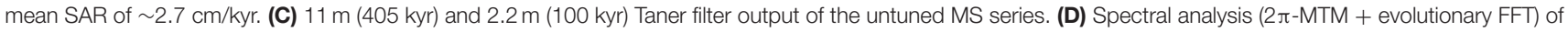
the 405 kyr-tuned MS series and (E) \% $\mathrm{CaCO}_{3}$ series.

be triggered by tropical humid climate which results in an enrichment of kaolinite and illite in marls, while this process is relatively weaker during the deposition of carbonate beds. According to the equation of linear regression between MS and $\% \mathrm{CaCO}_{3}$ (top left graph in Figure 3), the intercept value is $72 \times 10^{-9} \mathrm{~m}^{3} / \mathrm{kg}$ (when $\% \mathrm{CaCO}_{3}=0$ ). This value falls centered in the full range of paramagnetic minerals proposed by Walden et al. (1999), which are dominant in marls. In other words, the MS values are essentially carried by paramagnetic minerals while their fluctuations are governed by dilution from the diamagnetic $\mathrm{CaCO}_{3}$ mineral (Martinez et al., 2012, 2020; Martinez, 2018). This suggests that clay minerals coming from clastic sediments are considered here as indicative of the fluctuations in terrigenous supply into a background of carbonate production in the near-shore marine environment (Kodama et al., 2010; Gong et al., 2017; Minguez and Kodama, 2017). In a similar context, Moiroud et al. (2012) carried out a cyclostratigraphic study on Mesozoic hemipelagic marl-limestone rhythmites of the Río Argos section (Betic Cordillera, Southeastern Spain). They demonstrated that paramagnetic clay minerals are reliable proxies to record high-frequency climate fluctuations triggered by orbital forcing at several scales, including precession, obliquity, and eccentricity.

\section{Variations of the Sediment Accumulation Rate}

Two independent evolutive spectral analysis techniques (eTimeOpt and eCOCO) were applied to track the variations of SAR. We compared them with results from the EHA method (Figure 9) to check whether they correlate together giving similar trends of SAR along the section. The EHA technique was carried out separately for each orbital parameter to reduce the effect of power scale on the detection of orbital frequencies. The Figure 9 shows that the variation of the long orbital eccentricity is more compatible with SARs revealed by the eTimeOpt method whereas the other orbital parameters (short eccentricity, obliquity and precession) fit much better the eCOCO results (compare the indicative SARs arrows in Figure 9). The fact that more astronomical components are fitting for the eCOCO method led us to give more reliability on the eCOCO SARs.

In Figure 10, we plotted the variations of SAR (result of the eCOCO analysis) against the sequence stratigraphic interpretation as well as the paleontological results of Schnyder et al. (2005) on the same section. It seems that this SAR goes in line with major sea-level change along the section. Indeed, the SAR presents a clear increase in the middle part (24-31 m) of the record, which is as the same time as the deposition of the HST and LST (compare Figures 10B,E). This is consistent 


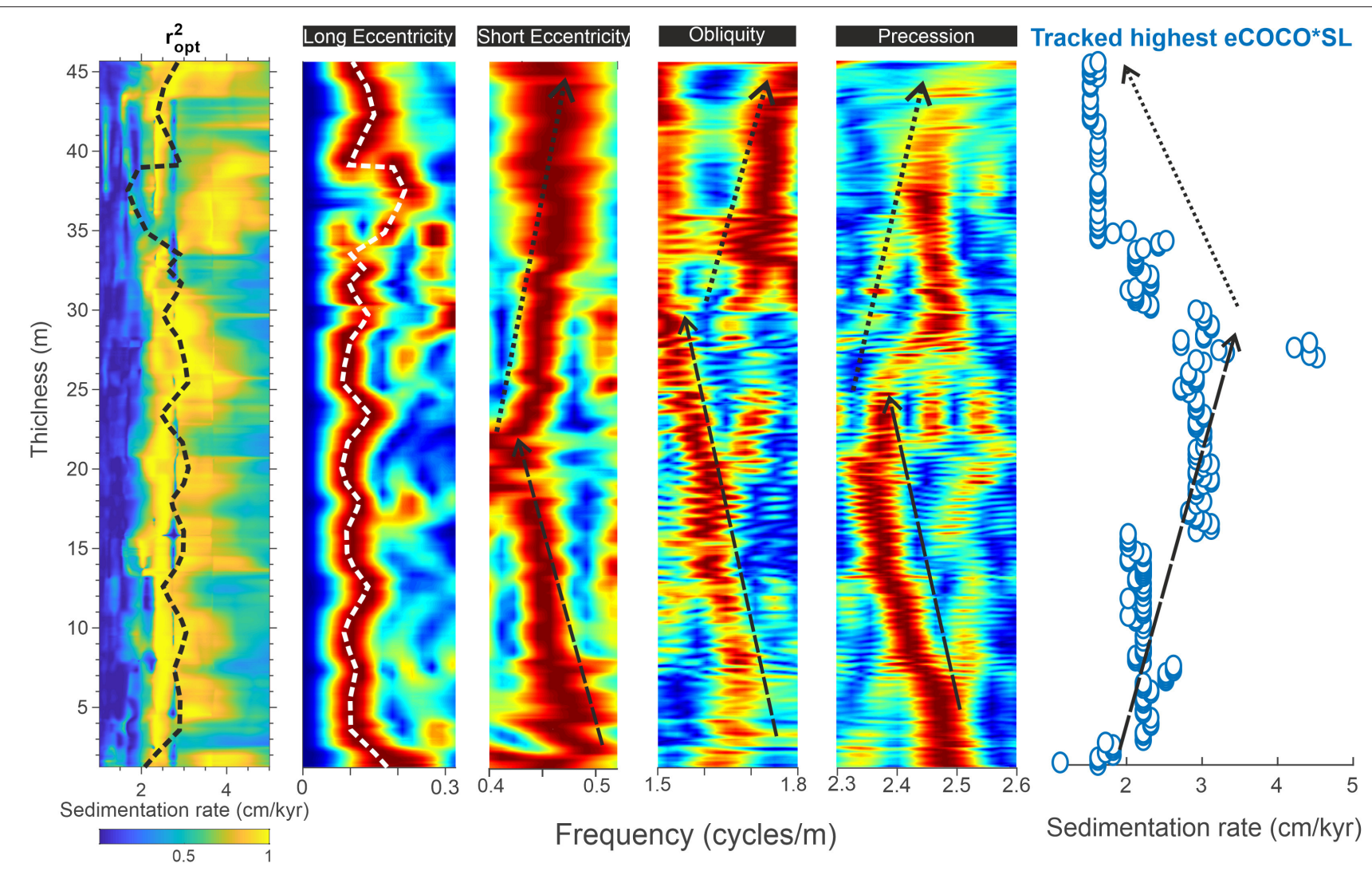

FIGURE 9 | Comparison of the EHA with results from eTimeOpt (extreme left) and eCOCO (extreme right). EHA was applied independently for each orbital parameter apart to allow a better expression of each corresponding amplitude. Dashed arrows indicate increasing SARs while the dotted ones indicate decreasing SARs.

with the paleontological data that indicate increasing detrital input spurred by the relative sea-level fall during the late Early Berriasian as proven by the dominant total palynofacies and spores/pollen in the upper part of the section (Schnyder et al., 2005) (Figures 10F-H).

The evolution of SAR (Figure 10B) exhibits two abrupt decreases at ca. 32 and $35 \mathrm{~m}$ as the lithology changes from dominant marl to medium-thick limestone beds. Consequently, the marls are interpreted, relative to carbonates, as deposited with higher SARs. This could be explained by the increased runoff and continental detrital input during the deposition of marls (as explained previously in section Cyclostratigraphic Analysis). In contrast, carbonate sedimentation seems to had occurred with lower SAR than marls that is why the SAR decreases significantly upward the section even though DYNOT and $\rho 1$ (Figure 10C) and paleontological data (Figures 10F,G) indicate an obvious contemporaneous sea-level fall. Notably, the eCOCO results, including the evolutive null hypothesis test $\mathrm{H} 0$ (Figure 7), display obvious perturbations (the least $\mathrm{COCO}$ values across the eCOCO map) along the stratigraphic interval ca. 35-40 m. Interestingly, this discontinuity is parallel to the major shift in the DYNOT curve toward higher values (Figure 10C) that could indicate shallower sedimentary environments. This suggests that the eCOCO analysis could also help to evaluate the depositional environments stability/instability during major sealevel fluctuations (Wang et al., 2020).

\section{Application of Sedimentary Noise Modeling for Sea-Level Change}

For multi-million-year-long deep-time datasets from marginal marine environments, DYNOT and $\rho 1$ models can be used to provide an independent, high-resolution sea-level curve ( $\mathrm{Li}$ et al., 2018a). Dynamic noise in the global sea-level curve may also be linked to changes in the Earth's climate state (Li et al., 2018a). However, the utility and efficacity of the sedimentary noise models is still being explored. Hitherto, only few studies attempted to establish links between sealevel change and DYNOT and $\rho 1$ models (Li et al., 2018a; Wang et al., 2020; Xu et al., 2021). While Li et al., 2018a dealt with Triassic marine sedimentary successions, Wang et al. (2020) focused rather on a paleolake fillings across the Eocene-Oligocene transition. Both studies have been carried out using Gamma Ray (GR) records as a paleoclimate proxy. This study provides a relatively different paleoenvironmental context using MS variations to assess and widen the validity of this method.

We applied the DYNOT and $\rho 1$ models on the MS series of the studied interval (Figure 10C). DYNOT and $\rho 1$ models with a 400 kyr running window correlate well with each other but in 


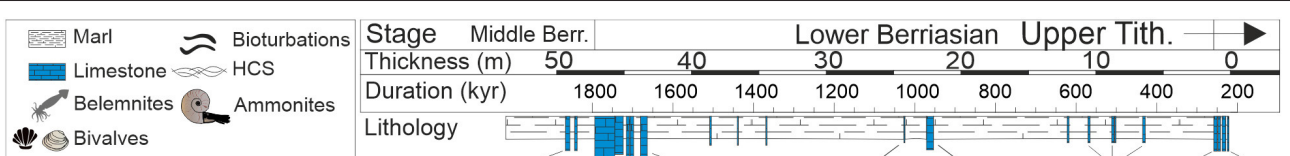

Fossils / Sedimentary stuctures

Tuned MS (unitless)

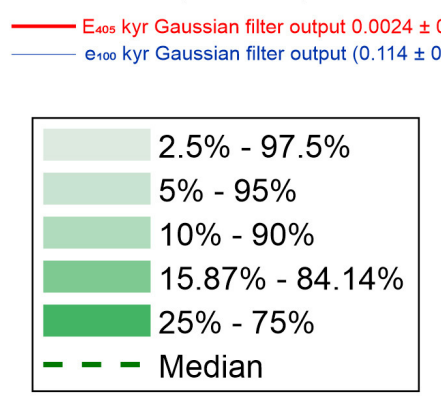

\section{$\Leftrightarrow$}

II III
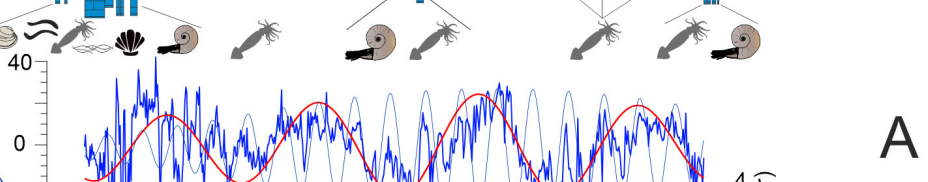
$-40=$
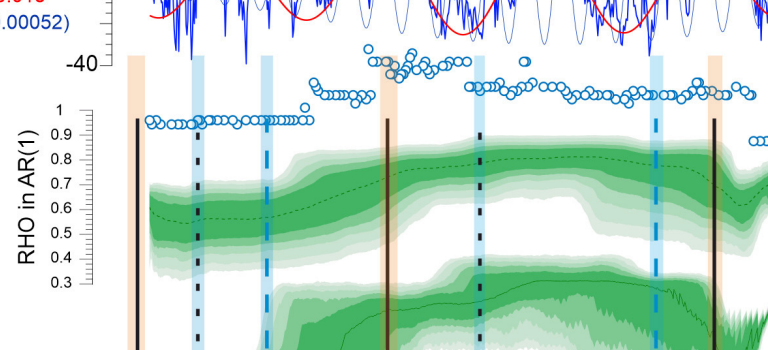

-3 है

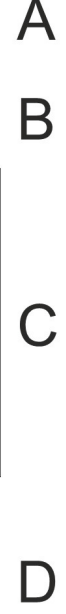

Long term and short term sea level curves

100

Sea level events
(Sequence boundaries)

$50 \mathrm{~m}$

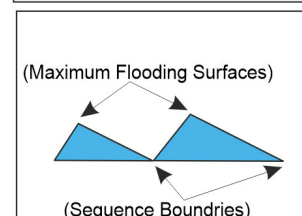

(Sequence Boundries)

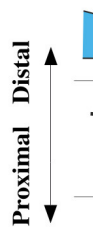

\#..."- MFS

ana=men TS

$\longrightarrow$ SB

Mean size of

opaque phytoclasts $(\mu \mathrm{m})$

Number of

dinoflagellate species 20
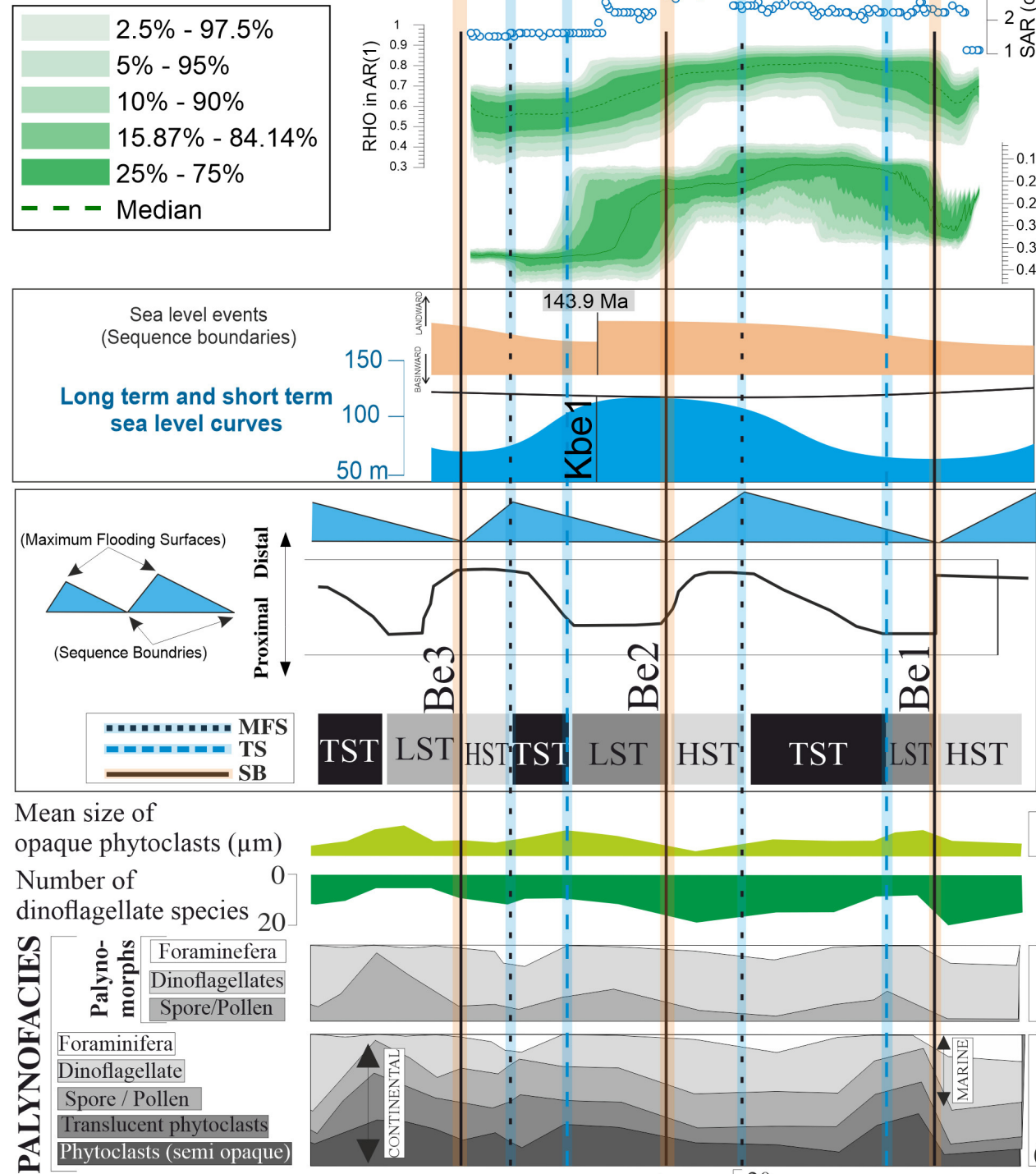

心

B

C

0.2 는

0.3 ठ

0.35

0.4
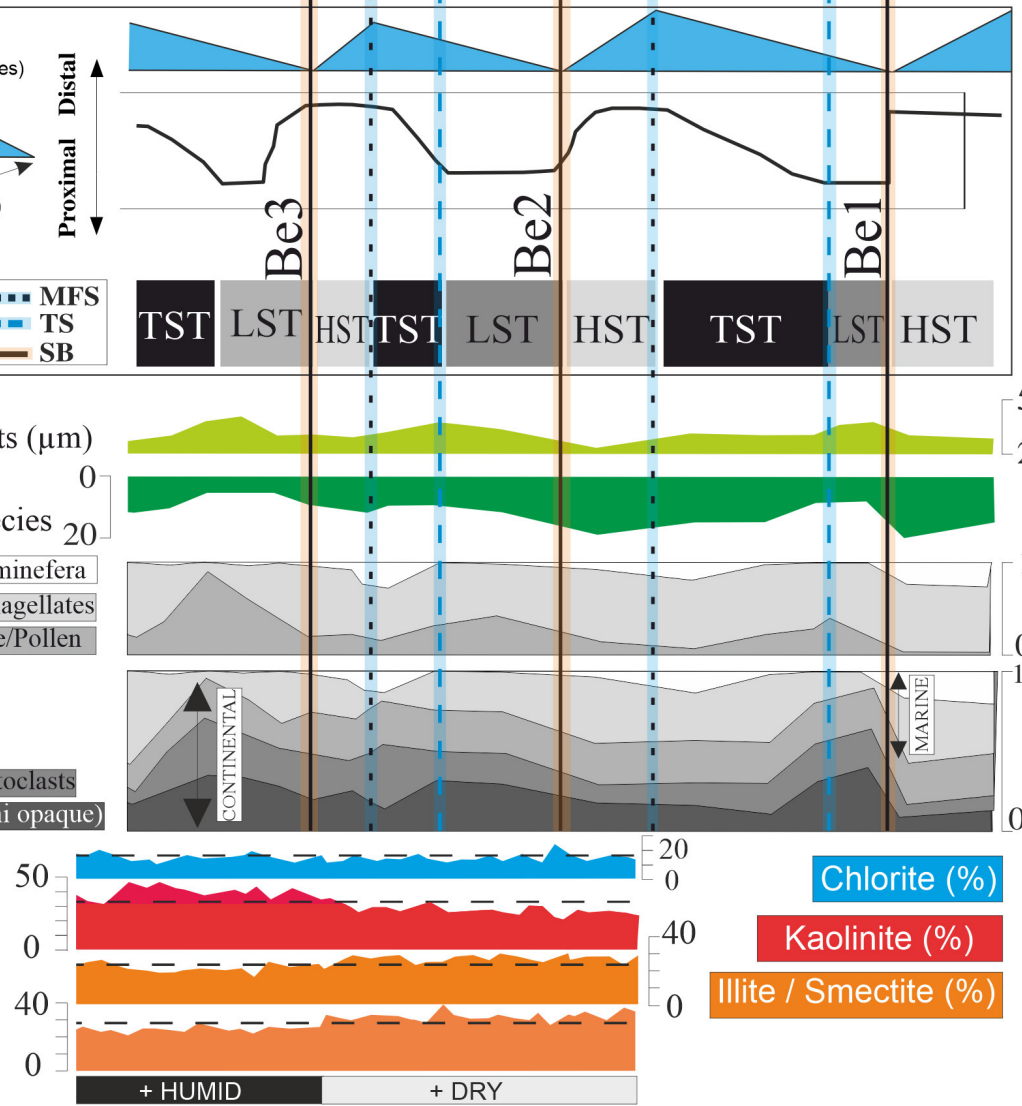

Chlorite (\%)

Kaolinite (\%)

Illite / Smectite (\%)

${ }_{20}^{50 \mu \mathrm{m}} \mathrm{F}$

E

F

$-100 \%$

0

$\mathrm{H}$

FIGURE 10 | Sequence stratigraphy and paleoclimate change during the Early Berriasian in central Tunisia. Time scale and biostratigraphy are from our ATS (current study) and M'Rabet (1981, 1987), respectively. (A) MS series and filtered long- and short eccentricity cycles. (B) Tracked highest eCOCO $\times$ SL (Results), (C) DYNOT and $\rho 1$ models of the MS series. The DYNOT and $\rho 1$ were estimated using a running window of 400, $5 \mathrm{kyr}$ step and a sample rate between 2.26 and $3.18 \mathrm{kyr}$.

(Continued) 
FIGURE 10 | Confidence levels were estimated by a Monte Carlo analysis with 5,000 iterations. (D) Sequences and global sea-level variations reported by Haq (2014). (E) Local sequences and seal-level variations estimated by Schnyder et al. (2005) for the lower Sidi Khalif Formation at Jebel Meloussi locality. (F-H) Synthesis of the palynofacies data in the lower Sidi Kralif Formation at the Jebel Meloussi (modified after Schnyder et al., 2005). (I) Clay mineral percentages (modified after Schnyder et al., 2005).

an opposite pattern. To compare the noise models (DYNOT and $\rho 1)$ with major 3rd order sea-level fluctuations, we proposed the global chart of sea-level change of Haq (2014) (Figure 10D) and an additional local eustatic profile proposed by the palynologic data of Schnyder et al. (2005) (Figure 10E).

At the global scale of sea-level change, KBe1 (143.9 Ma) is the main Early Berriasian eustatic event which marks a minor sea-level fall recorded in the western European basins (Hardenbol and Robaszynski, 1998; Haq, 2014), as well as in the Russian Platform (Sahagian et al., 1996). The sedimentary noise models of sea-level change in central Tunisia correlate with this major eustatic change (compare Figures 10C-E). The eustatic variations interpreted from the sedimentary noise models at Jebel Meloussi are supported by field observations at the outcrop and by MS variations. For example, the sequence boundary $\mathrm{KBe} 1$ in Figure 10D corresponds to the highest noise value $(\mathrm{DYNOT}=0.37)$.

At the local scale, Schnyder et al. (2005) reported a succession of at least three complete sedimentary sequences, namely Be1, $\mathrm{Be} 2$, and $\mathrm{Be} 3$ (Figure 10E) which were estimated to be the Lower Berriasian sequences of Hardenbol et al. (1998). The interpreted sequence boundaries $\mathrm{Be} 1, \mathrm{Be} 2$, and $\mathrm{Be} 3$ also coincide with elevated DYNOT except for $\mathrm{Be} 2$ with a slight temporal lag that could be related to the mis-fitting of the sequence stratigraphic limits of Schnyder et al. (2005) to our section. This is because the superposition of two independent data (the dataset of Schnyder et al., 2005 and our own data) resulting from the study of the same section separately could result in some slight (more or less) lag in chronostratigraphic context. Hence, it is worth further considering this sequence boundary $(\mathrm{Be} 2)$ and rescale theoretically the current ATS which would result to shifting the Be2 event toward higher DYNOT values.

Interestingly, we observe an increasing trend in the DYNOT curve toward the upper part of the section which is consistent with major lithologic changes from thin bedded marly sediments to medium-thick limestone beds (Figure 10) indicating sea-level fall characterized by proximal ramp sedimentary environments. Moreover, sedimentary structures and fossil content indicative of high-energy and shallow water conditions, e.g., bivalves, ripples, and cross stratifications (beds 17 and 18 in Figures 2,3), correlate with increased noise levels indicative of shallow sea levels. Indeed, sedimentary noise can come from instability in depositional environments as discussed above. Also, it may be related to abrupt change in paleoclimatic conditions (Meyers and Hinnov, 2010; Meyers, 2019), which is observed in the "noisiest" part of the section $(35-47 \mathrm{~m})$. This interval is marked by a turnover from arid condition to more humid conditions (discussed later in section Application of Sedimentary Noise Modeling for SeaLevel Change). The DYNOT values appear to increase also when the used proxy (MS) displays higher contrast between its least and highest values (compare Figures 10A,C).
Likewise, Li et al. (2018a) documented very similar features between the DYNOT model and lithologic behavior from two Early Triassic marine sections in South China. Those authors outlined mainly four sequence boundaries in their sections, which (three out of four) correspond to higher DYNOT values and are coherent with lithologic change that indicates sea-level falls. These constatations are very comparable to those of our case study.

On the other hand, the increase in the proportions of kaolinite at ca. $47 \mathrm{~m}$ (Schnyder et al., 2005) is located in a 2-m thick limestone bed rich in ammonite and belemnite corresponding to an MFS indicated by a peak in relative abundance of dinoflagellates and foraminifera, the specific diversity of dinoflagellates, as well as a reduction in the size of opaque phytoclasts [Figures 10F-H, Schnyder et al., 2005)]. This MFS, placed around the lower Berriasian-middle Berriasian boundary, at the top of callpinellids zone B, is interpreted by Schnyder et al. (2005) as the MFS of the Be2 sequence of Hardenbol et al. (1998). However, the DYNOT model shows higher values in this part of the section (up to 0.4). We, thus, associate this Be2 MFS to an eustatic peak at the fourth order preceding the general drop in sea level relative to the middle/upper Berriasian transition (Jacquin et al., 1998).

\section{Paleoenvironmental Context of the Recorded Milankovitch Cycles}

Depositional environments respond to climate, tectonic motions and sea-level change, but this response is mediated by the so-called "environmental shredding" which can fully destroys sedimentary signals of external forcing (e.g., Milankovitch cycles) (Jerolmack and Paola, 2010).

In our section, HCS structures and bioturbations can also lead to the distortion of the recording of the paleoclimate information. A critical look at the precessional cycles (22 kyr, Figure 9, rightmost graph) shows that this astronomical frequency is wellrecorded over the section. The only shredded parts occur at (1) ca. $25-27 \mathrm{~m}$ and at (2) ca. 43-45 m. For the first interval (1), the disturbance could be related to the relatively low sampling resolution because the calculated SAR is the highest all along the studied interval. Strong condensation could be another possible reason for the diminish of the precession spectral power at this interval (25-27 m); condensations may lead to aliasing, that in turn, cause weakening of spectral powers and high background noise near the highest frequency that can be detected (Nyquist Frequency) (Martinez et al., 2013). The second case (2) could be explained by a likely local effect of environmental shredding as witness the HCS structures and bioturbations (Figures 3, 10A) and also confirmed by the highest DYNOT values (Figure 10C).

Likewise, the obliquity cycles are interestingly wellrecorded in the EHA (Figure 9) but they are weaker in the lowermost part (ca. $0-5 \mathrm{~m}$ and ca. $30 \mathrm{~m}$ ) which rises attention. 
Notwithstanding, obliquity is expected to be badly visualized at lower paleolatitudes. Nonetheless, some previous works have reported strong obliquity expression unlikely to be observed at lower latitudes (Gunderson et al., 2013; Kodama, 2019).

Over and above that, central Tunisia has been relatively quiescent during the $\mathrm{J}-\mathrm{C}$ transition. Also, there is no sedimentological evidence, nor published works that report a contemporaneous nearby volcanic activity that could amplify the effect of autogenic process on the encoding of Milankovitch cycles. In conclusion, our arguments corroborate that environmental shredding is not at a similar time and amplitude scale as precession and obliquity; therefore, it does not interfere significantly with the recording of these cycles.

\section{Paleoclimate Implications: The Lower Berriasian Arid Climate}

The main climatic event during the Berriasian occurred across the lower/middle Berriasian boundary. It is marked by a turnover from dry to more humid conditions indicated by a drastic change in clay mineralogy (Figure 10I) in the southern Tethys margin (Daoudi et al., 1989; Daoudi and Deconinck, 1994; Schnyder et al., 2005) as well as in the northern Tethys margins (Deconinck, 1987, 1993; Rasplus et al., 1987; Schnyder, 2003). Our MS data (Figure 3) may indicate this dry to humid transition, through a gradual upward increase as the detrital input continue to feed the basin. According to the model of Mutterlose and Ruffell (1999), weathering conditions that may lead to the deposition of marl and limestones into a basin depends strongly on the paleoclimatic conditions. The same model proposes that MS values should increase in line with kaolinite and illite percentages under a tropical humid condition, whereas a semi-arid (dry) climate conditions would result in less runoff and thus lower MS values but higher I/S concentrations. This model is in a good agreement with our results (compare Figures 10A,J) throughout the early/middle Berriasian climate turnover: increasing MS (Figure 3) and XRF (Figure 4) values in the upper part of the section coincide with a noticeable higher concentration in \%kaolinite and a slight decrease in I/S clay minerals. Also, it is worth noting that the E405 and e100 filters output display a less dominant amplitude in the upper part of the section (compare Figures 10A-J), i.e., toward the upper Lower Berriasian stratigraphic series. This may imply that this climatic turnover from dry to more humid condition had occurred under the control of both long and short eccentricity cycles.

\section{CONCLUSIONS}

High-resolution cyclostratigraphic investigation from MS and $\% \mathrm{CaCO}_{3}$ proxies was undertaken on the Lower Berriasian sedimentary series in central Tunisia (Southern Tethys). This study allowed to depict the following points:

(1) The first outcome of this study is a floating astronomical timescale (ATS) for the target section.

(2) Geochemical investigation using major and trace elements (XRF analysis) helped as a preliminary test to check the validity of the MS signal as a paleoclimate proxy for such study.
(3) Various techniques of spectral analysis and modeling of sediment accumulation rate have been used to reach an optimal orbital model. Four long eccentricity cycles (E405) have been identified through the tuned MS stratigraphic series which points to a total duration of $\sim 1.6 \mathrm{Myr}$. The resulting floating ATS was tuned to the La2004 solution which allowed to propose an age constraint between 145.13 and $143.57 \mathrm{Ma}$ for the Lower Sidi Khalif Formation.

(4) Three objective tests of sediment accumulation rate (COCO, TimeOpt and ASM) have been applied on the MS series to unravel the vertical variations in SARs. These latter are ranging from 1.3 to $4.5 \mathrm{~cm} / \mathrm{kyr}$ : the middle part has the highest values and the upper part has the least ones.

(5) Moreover, the application of the DYNOT and $\rho 1$ noise modeling for sea-level change has allowed to reconstruct a local short-term eustatic profile, showing a similar trend to those reported by previous published studies, and is consistent with major SAR and lithological changes along the section.

(6) In terms of paleoclimate change, this study showed that the main climate turnover from arid to more humid condition across the lower/middle Berriasian may had occurred under the control of long and short orbital eccentricity cycles.

\section{DATA AVAILABILITY STATEMENT}

The raw data supporting the conclusions of this article will be made available by the authors, without undue reservation.

\section{AUTHOR CONTRIBUTIONS}

This work comes as a part of the cyclostratigraphy project across the Jurassic-Cretaceous transition in Tunisia which was proposed by CY. HO planned the study, measured the dataset, and carried out the spectral analysis and modeling techniques. $\mathrm{AD}$ helped on the spectral analysis on the Acycle software and Astrochron package, on the interpretation of the results and on the writing of the manuscript. All authors provided a direct scientific contribution to this article.

\section{FUNDING}

AD acknowledges the FNRS Grant PDR T.0051.19.

\section{ACKNOWLEDGMENTS}

We are grateful to the UNESCO International Geoscience Program (IGCP-652) for their courses and training on cyclostratigraphy and astrochronology. Warmly thanks to Dr. Adnen Lafi and Dr. Mouna Amami for guidance and help in the field sampling campaign.

\section{SUPPLEMENTARY MATERIAL}

The Supplementary Material for this article can be found online at: https://www.frontiersin.org/articles/10.3389/feart. 2021.638441/full\#supplementary-material 


\section{REFERENCES}

Allen, P. (1981). Pursuit of Wealden models. J. Geol. Soc. 138, 433-442.

Allen, P. (1998). Purbeck-Wealden (early Cretaceous) climates. Proc. Geol. Ass. $109,197-236$.

Aswasereelert, W., Meyers, S. R., Carroll, A. R., Peters, S. E., Smith, M. E., and Feigl, K. L. (2013). Basin-scale cyclostratigraphy of the Green River formation, Wyoming, GSA. Bulletin 125, 216-228. doi: 10.1130/ B30541.1

Ben Nsir, S., and Boughdiri, M. (2017). Commentaires sur: "Biozones de calpionelles et d'ammonites du Berriasien inférieur et moyen de la Formation Sidi Khalif au Jebel Meloussi, Tunisie centrale" par Kamel Maalaoui and Fouad Zargouni. Rev. Paléobiol. 35, 561-569.

Ben Nsir, S., Boughdiri, M., Cherif, I., Bahrouni, N., Ferchichi, R., and Zrelli, A. (2019). "Berriasian ammonite and calpionellid associations from the NorthSouth range of Central Tunisia: updated biozonation, regional geodynamic context and paleobiogeography," in First Conference of the Arabian Journal of Geosciences, 12-15 November 2018 (Hammamet).

Boulila, S., Galbrun, B., Hinnov, L. A., and Collin, P. Y. (2008). Highresolution cyclostratigraphic analysis from magnetic susceptibility in a Lower Kimmeridgian (Upper Jurassic) marl-limestone succession (La Méouge, Vocontian Basin, France). Sediment. Geol. 203, 54-63. doi: 10.1016/j.sedgeo.2007.10.004

Burollet, P. F. (1956). Contribution à l'étude stratigraphique de la Tunisie centrale. Ann. Mines Géol. Tunis 18:345.

Busnardo, R., Donze, P., Khessibi, M., Le Hegarat, G., Memmi, L., and M'Rabet, A. (1981). La formation Sidi Kralif (Tithonien-Berriasien) en Tunisie centrale, synthèse stratigraphique et sédimentologique. Ann. Mines Géol. Tunis $31,115-122$

Busnardo, R., Donze, P., Le Hegarat, G., Memmi, L., and M'Rabet, A. (1976). Précisions biostratigraphiques nouvelles sur le Berriasien des Djebel Nara et Sidi Kralif (Tunisie Centrale). Géobios 9, 231-249. doi: 10.1016/S0016-6995(76)80033-2

Calvert, S. E., and Pedersen, T. F. (2007). "Elemental proxies for palaeoclimatic and palaeo-ceanographic variability in marine sediments: interpretation and application," in Developments in Marine Geology, eds H. M. Claude and D. V. Anne (Amsterdam: Elsevier), 567-644.

Da Silva, A. C., De Vleeschouwer, D., Boulvain, F., Claeys, P., Fagel, N., Humblet, M., et al. (2013). Magnetic susceptibility as a high-resolution correlation tool and as a climatic proxy in Paleozoic rocks - merits and pitfalls: examples from the Devonian in Belgium. Mar. Pet. Geol. 46, 173-189. doi: 10.1016/j.marpetgeo.2013.06.012

Daoudi, L., and Deconinck, J.-F. (1994). Contrôles paléogéographiques et diagénétiques des successions sédimentaires argileuses du bassin atlasique au Crétacé (Haut-Atlas occidental, Maroc). J. Afr. Earth Sci. 8, 123-134. doi: 10.1016/0899-5362(94)90025-6

Daoudi, L., Deconinck, J. F., Beauchamp, J., and Debrabant, P. (1989). Minéraux argileux du bassin d'Agadir (Maroc) au Jurassique supérieur- Crétacé. Comparaison avec le domaine est-atlantique voisin. Ann. Soc. Géol. Nord 108, 15-24.

De Vleeschouwer, D., Boulvain, F., Da Silva, A. C., Pas, D., Labaye, C., and Claeys, P. (2015). The astronomical calibration of the Givetian (Middle Devonian) timescale (Dinant Synclinorium, Belgium). Geol. Soc. Spec. Publ. 414, 245-256. doi: $10.1144 /$ SP414.3

Deconinck, J. F. (1987). Minéraux argileux des faciès purbéckiens: Jura suisse et français, Dorset (Angleterre), et Boulonnais (France). Ann. Soc. Géol. Nord, 106, 285-297.

Deconinck, J. F. (1993). Clay mineralogy of the Upper Tithonian-Berriasian deep-sea carbonates of the Vocontian Trough (SE France): relationships with sequence stratigraphy. Bull. Centres Rech. Explor. Prod. Elf-Aquitaine $17,223-234$

Deconinck, J. F., and Strasser, A. (1987). Sedimentology, clay mineralogy and depositional environments of Purbeckian green marls (Swiss and French Jura). Eclogae Geol. Helv. 80, 753-772.

Ellwood, B. B., Crick, R. E., El Hassani, A., Benoist, S. L., and Young, R. H. (2000). Magnetosusceptibility event and cyclostratigraphy method applied to marine rocks: detrital input versus carbonate productivity.
Geology 28, 1135-1138. doi: 10.1130/0091-7613(2000)28<1135:MEACMA $>2$. $0 . \mathrm{CO} ; 2$

Gong, Z., Kodama, K. P., and Li, Y. (2017). Rock magnetic cyclostratigraphy of the Doushantuo Formation, South China and its implications for the duration of the Shuram carbon isotope excursion. Precambrian Res. 289, 62-74. doi: 10.1016/j.precamres.2016.12.002

Gradstein, F. M. (2012). "Introduction," in The Geologic Time Scale eds F. M. Gradstein, J. G. Ogg, M. D. Schmitz, and G. M. Ogg (Amsterdam: Elsevier), $1-29$.

Granier, B. R. C., Ferry, S., and Benzaggagh, M. (2020). A critical look at Tré Maroua (Le Saix, Hautes-Alpes, France), the berriasian GSSP candidate section. Carnets Geol. 20, 1-17. doi: 10.4267/2042/70714

Gunderson, K. L., Kodama, K. P., Anastasio, D. J., and Pazzaglia, F. J., et al. (2013). Rock-magnetic cyclostratigraphy for the Late Pliocene-Early Pleistocene Stirone section, Northern Apennine mountain front, Italy. Geol. Soc. Spec. Publ. 373, 309-323. doi: 10.1144/SP373.8

Hallam, A. (1984). Continental humid and arid zones during the Jurassic and Cretaceous. Palaeogeogr. Palaeoclimatol. Palaeoecol. 47, 195-223. doi: 10.1016/0031-0182(84)90094-4

Hallam, A. (1985). A review of Mesozoic climates. J. Geol. Soc. Spec. Publ. 142, 433-445. doi: 10.1144/gsjgs.142.3.0433

Hallam, A. (1986). Role of climate in affecting late Jurassic and early Cretaceous sedimentation in the North Atlantic. Geol. Soc. Spec. Publ. 21, 277-281. doi: 10.1144/GSL.SP.1986.021.01.20

Hallam, A., Grose, J. A., and Ruffell, A. H. (1991). Palaeoclimatic significance of changes in clay mineralogy across the Jurassic-Cretaceous boundary in England and France. Palaeogeogr. Palaeoclimatol. Palaeoecol. 81, 173-187. doi: 10.1016/0031-0182(91)90146-I

Haq, B. U. (2014). Cretaceous eustasy revisited. Glob. Planet. Change 113, 44-58. doi: 10.1016/j.gloplacha.2013.12.007

Hardenbol, J., and Robaszynski, F. (1998). Introduction to the upper Cretaceous. SEPM Spec. Publ. 60, 329-332.

Hardenbol, J., Thierry, J., Farley, M. B., Jacquin, T., Graciansky, P. C., and Vail, P. R. (1998). Mesozoic and Cenozoic sequence chronostratigraphic framework of European Basins. SEPM Spec. Publ. 60, 3-13.

Hilgen, F., Zeeden, C., and Laskar, J. (2020). Paleoclimate records reveal elusive 200-kyr eccentricity cycle for the first time. Global Planet. Change 194:103296. doi: 10.1016/j.gloplacha.2020.103296

Hilgen, F. J., Hinnov, L. A., Abdul Aziz, H., Abels, H. A., Batenburg, S., Bosmans, J. H. C., et al. (2014). "Stratigraphic continuity and fragmentary sedimentation: the success of cyclostratigraphy as a part of integrated stratigraphy," in Strata and Time: Probing the Gaps in Our Understanding, eds D. G. Smith, R. J. Bailey, P. M. Burgess, and A. J. Fraser (London: Geological Society), 404.

Hinnov, L. A. (2013). Cyclostratigraphy and its revolutionizing applications in the earth and planetary sciences. Bull. Geol. Society Am. 125, 1703-1734. doi: 10.1130/B30934.1

Hinnov, L. A., and Ogg, J. G. (2007). Cyclostratigraphy and the astronomical time scale. Stratigraphy 4, 239-251.

Hoedemaeker, P. J., and Leereveld, H. (1995). Biostratigraphy and sequence stratigraphy of the BerriasianeLowest Aptian (Lower Cretaceous) of the Rio Argos succession, Caravaca, SE Spain. Cretaceous Res. 16, 195-230. doi: 10.1006/cres.1995.1016

Huang, Z., Ogg, J. G., and Gradstein, F. M. (1993). A quantitative study of Lower Cretaceous cyclic sequences from the Atlantic Ocean and the Vocontian Basin (SE France). Paleoceanography 8, 275-291. doi: 10.1029/93PA00253

Husson, D. (2014). MathWorks File Exchange: RedNoise_ConfidenceLevels. Available online at: http://www.mathworks.com/matlabcentral/fileexchange/ 45539-rednoise confidencelevels/content/RedNoise_ConfidenceLevels/ RedConf.m (accessed April 28, 2014)

Jacquin, T., Dardeau, G., Durlet, C., De Graciansky P. C., and Hantzpergue, P. (1998). "The North-Sea cycle: an overview of 2nd-order transgressive/regressive facies cycles in western Europe," in Mesozoic and Cenozoic Sequence Stratigraphy of European Basins. 445-466.

Jerolmack, D. J., and Paola, C. (2010). Shredding of environmental signals by sediment transport. Geophys. Res. Lett. 37, 1-5. doi: 10.1029/2010GL044638

Kent, D. V., Olsen, P. E., Rasmussen, C., Lepre, C., Mundil, R., Irmis, R. B., et al. (2018). Empirical evidence for stability of the 405-kiloyear Jupiter-Venus 
eccentricity cycle over hundreds of millions of years. PNAS 115, 6153-6158. doi: $10.1073 /$ pnas. 1800891115

Kodama, K. P. (2019). Rock magnetic cyclostratigraphy of the carboniferous Mauch Chunk formation, Pottsville, PA, United States. Earth Sci. 7:285. doi: 10.3389/feart.2019.00285

Kodama, K. P., Anastasio, D. J., Newton, M. L., Pares, J. M., and Hinnov, L. A. (2010). High-resolution rock magnetic cyclostratigraphy in an Eocene flysch, Spanish Pyrenees. Geochem. Geophys. Geosyst. 11, 1-22. doi: 10.1029/2010GC003069

Kodama, K. P., and Hinnov, L. A. (2014). Rock Magnetic Cyclostratigraphy. Oxford: John Wiley and Sons, Ltd.

Kodama, K. P., and Hinnov, L. A. (2015). Rock Magnetic Cyclostratigraphy. Blackwell: Wiley, 165.

Lamas, F., Irigaray, C., Oteo, C., and Chacon, J. (2005). Selection of the most appropriate method to determine the carbonate content for engineering purposes with particular regard to marls. Eng. Geol. 81, 32-41. doi: 10.1016/j.enggeo.2005.07.005

Laskar, J., Robutel, P., Joutel, F., Gastineau, M., Correia, A. C. M., and Levrard, B. (2004). A long-term numerical solution for the insolation quantities of the Earth. Astron. Astrophys. 428, 261-285. doi: 10.1051/0004-6361:20041335

Laskar, L., Fienga, A., Gastineau, M., and Manche, H. (2011). La2010: a new orbital solution for the long-term motion of the Earth. Astron. Astrophys. 532:A89. doi: 10.1051/0004-6361/201116836

Li, M., Hinnov, L., and Lee, K. (2019a). Acycle: Time-series analysis software for paleoclimate research and education. Comput. Geosci. 127, 12-22. doi: 10.1016/j.cageo.2019.02.011

Li, M., Hinnov, L. A., Huang, C., and Ogg, J. G. (2018a). Sedimentary noise and sea levels linked to land-ocean water exchange and obliquity forcing. Nat. Commun. 9:1004. doi: 10.1038/s41467-018-03454-y

Li, M., Huang, C., Ogg, J., Zhang, Y., Hinnov, L., Wu, H., et al. (2019b). Paleoclimate proxies for cyclostratigraphy: comparative analysis using a Lower Triassic marine section in South China. Earth Sci. Rev. 189, 125-146. doi: 10.1016/j.earscirev.2019.01.011

Li, M., Kump, L. R., Hinnov, L. A., and Mann, M. E. (2018b). Tracking variable sedimentation rates and astronomical forcing in Phanerozoic paleoclimate proxy series with evolutionary correlation coefficients and hypothesis testing. Earth Planet. Sci. Lett. 501, 165-179. doi: 10.1016/j.epsl.2018.08.041

Li, M. S., Huang, C. J., Hinnov, L. A., Ogg, J., Chen, Z. Q., and Zhang, Y. (2016a). Obliquity forced climate during the early triassic hothouse in China. Geology 44, 623-626. doi: 10.1130/G37970.1

Li, M. S., Ogg, J., and Zhang, Y. (2016b). Astronomical tuning of the end-permian extinction and the early triassic epoch of south China and Germany. Earth Planet. Sci. Lett. 441, 10-25. doi: 10.1016/j.epsl.2016.02.017

Liu, W., Wu, H., Hinnov, L. A., Xi, D., He, H., Zhang, S., et al. (2020). Early cretaceous terrestrial milankovitch cycles in the Luanping Basin, North China and time constraints on early stage Jehol Biota evolution. Front. Earth Sci. 8:178. doi: $10.3389 /$ feart. 2020.00178

Ma, C., Meyers, S. R., and Sageman, B. B. (2019). Testing Late Cretaceous astronomical solutions in a 15 million year astrochronologic record from North America. Earth Planet Sci. Lett. 513, 1-11. doi: 10.1016/j.epsl.2019.01.053

Maalaoui, K., and Zargouni, F. (2016a). Biozones de calpionelles et d'ammonites du Berriaisien inférieur et moyen de la Formation Sidi Khalif au Jebel Meloussi, Tunisie centrale. Rev. Paléobiol. 35, 373-384. doi: 10.5281/zenodo.51883

Maalaoui, K., and Zargouni, F. (2016b). The Lower and Middle Berriasian in Central Tunisia: integrated ammonite and calpionellid biostratigraphy of the Sidi Kralif Formation. Acta Geol. Polonica 66,43-58. doi: 10.1515/agp-2016-0002

Martinez, M. (2018). "Mechanisms of preservation of the eccentricity and longerterm milankovitch cycles in detrital supply and carbonate production in hemipelagic marl-limestone alternations," in Stratigr. Timesc. 3, 189-218. doi: 10.1016/bs.sats.2018.08.002

Martinez, M., Aguado, R., Company, M., Sandoval, J., and Dogherty, O. (2020). Integrated astrochronology of the Barremian stage (Early Cretaceous) and its biostratigraphic subdivisions. Glob. Planet. Change 195:103368. doi: 10.1016/j.gloplacha.2020.103368

Martinez, M., Deconinck, J. F., Pellenard, P., Reboulet, S., and Riquier, L. (2013). Astrochronology of the Valanginian stage from reference sections (Vocontian Basin, France) and palaeoenvironmental implications for the Weissert event. Palaeogeogr. Palaeoclimatol. Palaeoecol. 376, 91-102. doi: 10.1016/j.palaeo.2013.02.021

Martinez, M., Pellenard, P., Deconinck, J.-F., Monna, F., Riquier, L., Boulila, S., et al. (2012). An orbital floating time scale of the Hauterivian/ Barremian GSSP from a magnetic susceptibility signal (Río Argos, Spain). Cretaceous Res. 36, 106-115. doi: 10.1016/j.cretres.2012.02.015

Mayer, H., and Appel, E. (1999). Milankovitch cyclicity and rock-magnetic signatures of palaeoclimatic change in the Early Cretaceous Biancone Formation of the Southern Alps, Italy. Cretaceous Res. 20, 189-214. doi: $10.1006 /$ cres. 1999.0145

Memmi, L. (1967). Succession de faunes dans le Tithonique supérieur et le Berriasien du Djebel Nara (Tunisie centrale). Bull. Soc. Géol. France 9, 267-272. doi: 10.2113/gssgfbull.S7-IX.2.267

Meyers, S. R. (2015). The evaluation of eccentricity-related amplitude modulation and bundling in paleoclimate dataastrochron: an inverse approach for astrochronologic testing and time scale optimization. Paleoceanography 30, 1625-1640. doi: 10.1002/2015PA002850

Meyers, S. R. (2019). Cyclostratigraphy and the problem of astrochronologic testing. Earth Sci. Rev. 190, 190-223. doi: 10.1016/j.earscirev.2018.11.015

Meyers, S. R., and Hinnov, L. A. (2010). Northern Hemisphere glaciation and the evolution of Plio-Pleistocene climate noise. Paleoceanography 25:PA3207. doi: 10.1029/2009PA001834

Meyers, S. R., and Malinverno, A. (2018). Proterozoic milankovitch cycles and the history of the solar system. Proc. Natl. Acad. Sci. U.S.A. 115, 6363-6368. doi: 10.1073/pnas.1717689115

Meyers, S. R., and Sageman, B. B. (2004). Detection, quantification, and significance of hiatuses in pelagic and hemipelagic strata. Earth Planet. Sci. Lett. 224, 55-72. doi: 10.1016/j.epsl.2004.05.003

Meyers, S. R., and Sageman, B. B. (2007). Quantification of deep-time orbital forcing by average spectral misfit. Am. J. Sci. 307, 773-792. doi: $10.2475 / 05.2007 .01$

Meyers, S. R., Sageman, B. B., and Hinnov, L. A. (2001). Integrated quantitative stratigraphy of the Cenomanian-turonian bridge creek limestone member using evolutive harmonic analysis and stratigraphic modeling. J. Sediment. Res. 71, 628-644. doi: 10.1306/012401710628

Minguez, D., and Kodama, K. P. (2017). Rock magnetic chronostratigraphy of the Shuram carbon isotope excursion : Wonoka Formation, Australia. Geology 45, 1-4. doi: 10.1130/G38572.1

Moiroud, M., Martinez, M., Deconinck, J., Monna, F., Pellenard, P., Riquier, L., et al. (2012). High-resolution clay mineralogy as a proxy for orbital tuning : example of the Hauterivian - Barremian transition in the Betic Cordillera (SE Spain). Sediment. Geol. 282, 336-346. doi: 10.1016/j.sedgeo.2012.10.004

M'Rabet, A. (1981). Stratigraphie, sédimentation et diagenèse carbonatée des séries du Crétacé inférieur de Tunisie centrale. [Thèse] Université Paris Sud, Orsay, France.

M'Rabet, A. (1987). Stratigraphie, sédimentation et diagenèse carbonatée des séries du Crétacé inférieur de la Tunisie centrale. Ann. Min. Géol. Tunis 30:412.

Muller, R. A., and MacDonald, G. J. (2000). Ice Ages and Astronomical Causes: Data, Spectral Analyses and Mechanisms. Chichester: Springer-Praxis.

Mutterlose, J., and Ruffell, A. H. (1999). Milankovitch-scale palaeoclimate changes in paledark bedding rhythms from the Early Cretaceous (Hauterivian and Barremian) of eastern England and northern Germany. Palaeogeogr. Palaeoclimatol. Palaeoecol. 154, 133-160. doi: 10.1016/S0031-0182(99)00107-8

Ogg, J. G., Hinnov, L. A., and Huang, C. (2012). “Cretaceous," The Geologic Time Scale eds F. M. Gradstein, J. G. Ogg, M. D. Schmitz, and G. M. Ogg (Amsterdam: Elsevier), 793-853.

Price, G. D. (1999). The evidence and implication of polar ice during the Mesozoic. Earth Sci. Rev. 48, 183-210. doi: 10.1016/S0012-8252(99)00048-3

Rasplus, L., Fourcade, S., Ambroise, D., Andeol, B., Azéma, J., Blanc, P., et al. (1987). Stratigraphie intégrée du sillon citrabétique (Sierra de Fontcalent, Province d'Alicante, Espagne). Geobios 20, 337-387. doi: 10.1016/S0016-6995(87)80047-5

Riquier, L., Averbuch, O., Devleeschouwer, X., and Tribovillard, N. (2010). Diagenetic ver-sus detrital origin of the magnetic susceptibility variations in some carbonate Frasnian-Famennian boundary sections from Northern Africa and Western Eu-rope: implications for paleoenvironmental reconstructions. Int. J. Earth Sci. 99, 57-73. doi: 10.1007/s00531-0090492-7 
Ruffell, A. H., and Rawson, P. F. (1994). Paleoclimate control on sequence stratigraphic patterns in the late Jurassic to mid-Cretaceous, with a case study from eastern England. Palaeogeogr. Palaeoclimatol. Palaeoecol. 110, 43-54. doi: 10.1016/0031-0182(94)90109-0

Sageman, B. B., S. E., Singer, B. S., Meyers, S. R., Siewert, S. E., Condon, D., et al. (2014). Integrating $40 \mathrm{Ar} / 39 \mathrm{Ar}, \mathrm{U}-\mathrm{Pb}$, and astronomical clocks in the Cretaceous Niobrara Formation, Western Interior Basin. Geol. Soc. Am. Bull. 126, 956-973. doi: 10.1130/B30929.1

Sahagian, D., Pinous, O., Olferiev, A., and Zakharov, V. (1996). Eustatic curve for the Middle Jurassic-Cretaceous based on Russian platform and Siberian stratigraphy: zonal resolution. AAPG Bull. 80, 1433-1458. doi: 10.1306/64ED9A56-1724-11D7-8645000102C1865D

Schnyder, J. (2003). Le passage Jurassique/Crétacé: événements instantanés, variations climatiques enregistrées dans les faciès purbéckiens français (Boulonnais, Charentes) et anglais (Dorset). Comparaison avec le domaine téthysien (Thèse de 3ème cycle), Universités de Lille, Paris, 389.

Schnyder, J., Gorin, G., Soussi, M., Baudin, F., and Deconinck, J. F. (2005). A record of the Jurassic/Cretaceous boundary climatic variation on the southern margin of the Tethys: clay minerals and palynofacies of the early Cretaceous Jebel Meloussi section (Central Tunisia, Sidi Kralif Formation). Bull. Soc. Géol. France 176, 171-182. doi: 10.2113/176.2.171

Sinnesael, M., De Vleeschouwer, D., Zeeden, C., Batenburg, S. J., Da Silva, A. C., de Winter, N. J., et al. (2019). The Cyclostratigraphy Intercomparison Project (CIP): consistency, merits and pitfalls. Earth Sci. Rev. 199:102965. doi: 10.1016/j.earscirev.2019.102965

Soussi, M. (2002). Le Jurassique de la Tunisie atlasique: stratigraphie, dynamique sédimentaire, paléogéographie et intérêt pétrolier. Docum. Lab. Geol. Lyon 157:363.

Strasser, A., Hilgen, F. J., and Heckel, P. H. (2007). Cyclostratigraphy - concepts, definitions, and applications. Newslett. Stratigr. 42, 75-114. doi: 10.1127/0078-0421/2006/0042-0075

Taner, M. (2000). Attributes Revisited. Technical Publication. Houston, TX: Rock Solid Images Inc.

Thomson, D. J. (1982). Spectrum estimation and harmonic analysis. Proc. IEEE 70, 1055-1096. doi: 10.1109/PROC.1982.12433

Torrence, C., and Compo, G. P. (1998). A practical guide to wavelet analysis. Bull. Am. Meteorol. Soc. 79, 61-78. doi: 10.1175/1520-0477(1998)079andlt;0061:APGTWAandgt;2.0.CO;2
Vennari, V. V., Lescano, M., Naipauer, M., Aguirre-Urreta, B., Concheyro, A. Schaltegger, U., et al. (2014). New constraints on the Jurassic-Cretaceous boundary in the High Andes using high-precision U-Pb data. Gondwana Res. 26, 374-385. doi: 10.1016/j.gr.2013.07.005

Walden, J., Oldfield, F., and Smith, J. (1999). Environmental Magnetism: A Practical Guide. Technical Guide $n^{\circ}$ 6. London: Quaternary Research Association.

Wang, M., Chena, H., Huang, C., Kemp, D. B., Xu, T., Zhang, H., et al. (2020). Astronomical forcing and sedimentary noise modeling of lake-level changes in the Paleogene Dongpu Depression of North China. Earth Planet. Sci. Lett. 535:116. doi: 10.1016/j.epsl.2020.116116

Weedon, G. P., Coe, A. L., and Gallois, R. W. (2004). Cyclostratigraphy, orbital tuning and inferred productivity for the type Kimmeridge Clay (Late Jurassic), southern England. J. Geol. Soc. Lond. 161, 655-666. doi: 10.1144/0016-764903-073

Wimbledon, W. A. P., Reháková, D., Svobodová, A., Elbra, T., Schnabl, P., Pruner, P., et al. (2020). The proposal of a GSSP for the Berriasian stage (Cretaceous system): part 2. Volumina Jurassica 18, 121-160. doi: 10.7306/ vj. 18.5

Wimbledon, W. A. P., Casellato, C. E., Rehákov,á, D., Bulot, L. G., Erba, E., Gardin, S., et al. (2011). Fixing a basal Berriasian and Jurassic-Cretaceous (J$\mathrm{K})$ boundary - is there perhaps some light at the end of the tunnel? Riv. Ital. Paleontol. Stratigr. 117, 295-307. doi: 10.13130/2039-4942/5976

$\mathrm{Xu}$, K., De Vleeschouwer, D., Vahlenkamp, M., Yang, R., and Chen, H. (2021). Reconstructing Eocene Eastern Indian Ocean dynamics using ocean-drilling stratigraphic records. Paleoceanogr. Paleoclimatol. 1-20. doi: $10.1029 / 2020 \mathrm{pa} 004116$

Conflict of Interest: The authors declare that the research was conducted in the absence of any commercial or financial relationships that could be construed as a potential conflict of interest.

Copyright (c) 2021 Omar, Da Silva and Yaich. This is an open-access article distributed under the terms of the Creative Commons Attribution License (CC BY). The use, distribution or reproduction in other forums is permitted, provided the original author(s) and the copyright owner(s) are credited and that the original publication in this journal is cited, in accordance with accepted academic practice. No use, distribution or reproduction is permitted which does not comply with these terms. 